\title{
Real GDP in Pre-War East Asia: A 1934-36 Benchmark Purchasing Power Parity Comparison with the U.S.
}

\author{
Kyoji Fukao \\ Institute of Economic Research \\ Hitotsubashi University \\ *Debin Ma (corresponding author) \\ Economic History Department, London School of Economics, U.K; \\ and National Graduate Institute for Policy Studies, Tokyo, Japan. \\ Tangjun Yuan \\ Institute of Economic Research \\ Hitotsubashi University
}

Feb. 2007

\begin{abstract}
This article provides estimates of purchasing power parity (PPP) converters for expenditure side GDP of Japan/China, Japan/U.S and China/US through a detailed matching of prices for more than 50 types of goods and services in private consumption and about 20 items or sectors for investment and government expenditure. Linking with the earlier studies on the price levels of Taiwan and Korea relative to Japan, we derive the mid1930 s benchmark PPP adjusted per capita income of Japan, China, Taiwan and Korea at $32 \%, 11 \%, 23 \%$, and $12 \%$ of the U.S. level respectively. These estimates corrected the consistent downward bias in East Asian income levels based on market exchange rate conversions. Compared with Angus Maddison's estimates based on the 1990 benchmark back-projection, our current-price based result are $18 \%$ and $44 \%$ lower for Japan and Korea and 4\% and 10\% higher for Taiwan and China respectively in the mid-1930s. We develop a preliminary theoretical and empirical framework to examine the possible source of the biases in the back-projection method. The article ends with a discussion on historical implications of our findings on the initial conditions and longterm growth dynamics in East Asia.
\end{abstract}

*Please direct all correspondence to Debin Ma, Economic History Department, London School of Economics, Houghton Street, London, WC2A, 2AE. Email: d.ma1@1se.ac.uk or debinma@hotmail.com.

We are grateful for Paul Rhode and John Devereux for pointing to us useful data sources. We thank Paul Rhode, John Devereux, Hak Kil Pyo, Jean Pascal Bassino, Prema-Chandra Athukorala, Konosuke Odaka and the participants of the UC Davis workshop June 1, 2005; the Vice-Presidential Session of the International Economic History Congress at Helsinki, in August, 2006, seminars at LSE and Oxford University. Our special thanks go to Angus Maddison for his careful reading and comments. This paper is partly funded by the NSF Global Prices and Income 1350-1950. project headed by Peter Lindert at UC Davis and the Ministry of Education $21 \mathrm{st}^{\mathrm{ts}}$ Century COE Program, .Research Unit for Statistical Analysis in Social Sciences,. headed by Osamu Saito at Hitotsubashi University. All errors are the responsibility of the authors. 


\section{Real GDP in Pre-War East Asia: a 1934-36 Benchmark Purchasing Power Parity Comparison with the U.S.}

Abstract: This article provides estimates of purchasing power parity (PPP) converters for expenditure side GDP of Japan/China, Japan/US and China/U.S through a detailed matching of prices for more than 50 types of goods and services in private consumption and about 20 items or sectors for investment and government expenditure. Linking with the earlier studies on the price levels of Taiwan and Korea relative to Japan, we derive the mid-1930s benchmark PPP adjusted per capita income of Japan, China, Taiwan and Korea at 32\%, $11 \%, 23 \%$, and $12 \%$ of the U.S. level respectively. These estimates corrected the consistent downward bias in East Asian income levels based on market exchange rate conversions. Compared with Angus Maddison's estimates based on the 1990 benchmark back-projection, our current-price based result are $18 \%$ and $44 \%$ lower for Japan and Korea and 4\% and 10\% higher for Taiwan and China respectively in the mid-1930s. We develop a preliminary theoretical and empirical framework to examine the possible source of the biases in the backprojection method. The article ends with a discussion on historical implications of our findings on the initial conditions and long-term growth dynamics in East Asia.

In the world history of modern economic growth, the East Asian miracle is a relatively recent phenomenon. The catch-up of Japan, Taiwan and Korea with the world's leading economies is a $20^{\text {th }}$ century, or more precisely, a post-WWII affair, while the economic surge of China is only a matter of the last two decades. However, as revealed by the burgeoning literature on economic growth, long-term or historical factors provide us with crucial insights into both the causal determinants and the mechanism of modern economic growth. What were the initial conditions of East Asian economies prior to their take-off? Were there shared vital historical factors behind their miracles?

These questions cannot be properly answered without long-term series of national accounts. Among the East Asian economies, the most consistent and reliable long-term GDP series going back to the late-19 $9^{\text {th }}$ century are available only for Japan, partly thanks to the efforts of the Long-Term Economic Statistics (LTES) project under the leadership of Kazushi Ohkawa at the Institute of Economic Research of Hitotsubashi University in Japan. ${ }^{1}$ The Hitotsubashi group extended this line of research to two former Japanese colonies, Taiwan and Korea, with the 1988 publication of a statistical volume compiled by Mizoguchi and Umemura. The volume provides annual estimates of GDP and its various components for these two economies during the period of Japanese occupation based on the detailed economic statistics of the colonial administrations. Compared with these countries, historical macroeconomic statistics for China remain sketchy. Solid economic statistics for standard national accounts are available only for the 1930s, which lay the foundation for the

${ }^{1}$ For Japan, there is the 14 volume LTES publication in Japanese. For an abridged English version, see the volume by Kazushi Ohkawa and Miyohei Shinohara. 
pioneering reconstruction of China's GDP for the period 1931-36 carried out by Ou et al. (1947), Liu (1947), and Liu and Yeh (1965).

These pre-war GDP series are all based on their domestic currencies. As is well-known, conversion of per capita incomes based on market exchange rates tends to systematically underestimate the real per capita income level of lower income countries since it fails to incorporate differences in the price level for nontradable goods (Balassa, 1964; Samuelson, 1964). Yet research on the construction of purchasing power parity (PPP) converters for GDP for the pre-war period, especially for developing countries such as those in East Asia, have barely started. The national accounts datasets based on PPP conversion by the renowned Penn World Table group only cover the post-War period. Angus Maddison is possibly the only scholar to have attempted a systematic reconstruction of long-term national accounts for most countries around the world. To arrive at globally comparable series for the pre-war period, Maddison relied on the use of 1990 benchmark PPPs to project per capita GDP values backward using domestic real per capita GDP growth rates. This methodology, adopted due to the absence of historical PPP converters, has its inherent index number problems associated with factors such as long-term relative shifts in a country's terms of trade and economic structure.

The present paper develops a full-fledged reconstruction of a three-way, bilateral expenditure PPPs for Japan, China and US for 1934-36. We conduct a detailed matching of the prices of more than 50 types of goods and services for private consumption and about 20 expenditure items for private investment and government expenditure. We find that average consumer prices in China in 1934-36 are about 73\% and 32\% of Japan and US respectively, while the average GDP price level in Japan is $43 \%$ that of the U.S. Linking with the Fukao, Ma and Yuan study (2006) on the relative price levels of Taiwan and Korea and using Japan as the bridge country, we derive the mid-1930s benchmark PPP-adjusted per capita income of Japan, China, Taiwan, and Korea at $32 \%, 11 \%, 23 \%$, and $12 \%$ of that of the U.S respectively. These figures are consistently higher than their corresponding per capita GDP estimates based on current market exchange rates, which are 14\%, 3.6\%, $9 \%$, and $5.2 \%$ of the U.S level respectively. On the other hand, in comparison with Maddison's 1990 benchmark back-projected estimate, our current price values (expressed in 1990 dollars) are 18\% and 44\% lower for Japan and Korea, but 4\% and 10\% higher for Taiwan and China respectively (Maddison 2003, p.182).

Our new estimates have large implications on both the levels and growth trajectories of these four East Asian economies. In particular, Japanese as well as Korean per capita incomes were lower than previously 
thought. In fact, comparing our estimate with the data for other countries provided in Maddison (2003) suggests that Japan's per capita income during this period was only marginally higher than those of Malaysia or the Philippines. In other words, Japan launched her full military venture on the Asian continent with a percapita income roughly comparable to some of the resource-rich Asian countries, most of which were still Western colonies. If we project backward or forward from our benchmark PPP estimates, our study sheds new light on the initial GDPs of Japan and East Asia both around the mid- $19^{\text {th }}$ century and the post-WWII period.

The remainder of this paper is divided into three sections followed by a summary. The first section provides a detailed explanation of our PPP estimation procedure and reports our current-price PPP estimates in 1934-36. In Section II we present our new estimates of per capita incomes in the four East Asian economies with the U.S and compare them with those based on current market exchange rates as well as the backward projection estimates. Section III discusses the index number biases embedded in the back-projection method. The summary section provides a brief discussion of our reassessment of initial conditions and long-term growth dynamics in East Asia based on our new findings.

\section{Current-Price PPP Estimates for 1934-36}

We adopt the methodology used by several rounds of the International Comparison Program (ICP) for the post-WWII benchmark periods. ${ }^{2}$ We choose the 1934-36 period as our benchmark for several reasons. First, this period has been consistently used as the benchmark in the LTES project. Second, for Japan and her two former colonies, 1934-36 was a period of relative economic and price stability, falling between the severe deflation that lead to Japan's banning of gold exports in 1931-32 and the economic dislocation of the late 1930s brought about by the outbreak of the Sino-Japanese War. In China, there was a major monetary reform by the Nationalist government in 1933 which succeeded in replacing the traditional silver-based monetary system with a modern unified currency under the control of a Central Bank. More importantly, for the 1931-36 period, we have the first reasonably reliable benchmark GDP estimate. And for East Asia in general, it was only during the 1930s that urban and rural household surveys became much more plentiful and reliable.

Our computation of relative price levels employs the standard binary matching of two countries. We derived the Fisher geometric mean as follows. For $N$ number of goods and services, the price level in the

\footnotetext{
${ }^{2}$ For the ICP study, see Heston and Summers 1993 and Maddison 1995
} 
currency of the numeraire or base country (sub- or superscripted as $B$ here) relative to the price level of country $i$ is calculated as follows:

$P_{i, B}^{B}=\frac{\sum p_{n}^{i} q_{n}^{B}}{\sum p_{n}^{B} q_{n}^{B}}=\frac{\sum \frac{p_{n}^{i}}{p_{n}^{J}} p_{n}^{B} q_{n}^{B}}{\sum p_{n}^{B} q_{n}^{B}}=\sum \frac{p_{n}^{i}}{p_{n}^{B}} \omega_{n}^{B}$

where $p_{n}{ }^{i}$ denotes absolute price level of commodities (or services) $n$ in country $i$ in base country currency and $\omega_{n}{ }^{B}$ denotes the consumption expenditure weight for the period of 1934-36. The summation sign is summed across $N$ types of goods and services. We use the average market exchange rate in 1934-36 for conversion of absolute price levels. The formula using the consumption weight of country $i$ is:

$$
P_{i, B}^{i}=\frac{\sum p_{n}^{i} q_{n}^{i}}{\sum p_{n}^{B} q_{n}^{i}}=\frac{\sum p_{n}^{i} q_{n}^{i}}{\sum \frac{p_{n}^{B}}{p_{n}^{i}} p_{n}^{i} q_{n}^{i}}=\frac{1}{\sum \frac{p_{n}^{B}}{p_{n}^{i}} \omega_{n}^{i}}
$$

Finally, the geometric average of the two price indices (the Fisher index) $P_{i, B}=\sqrt{P_{i, B}^{i} \times P_{i, B}^{B}}$ gives us country i's absolute price level relative to that of the base country.

\section{PPP Converter for Private Consumption: Japan and China}

The information on prices and expenditure weights for Japan is largely drawn from the earlier PPP study of Fukao, Ma, and Yuan, 2006. There, prices for each item in Japan in most cases are calculated as the simple average of the retail prices in 12 to 14 major cities. For China, we rely on more than 60 volumes of detailed retail price statistics compiled in 1955 by the Communist government. The volumes are titled "Gongnongye Shangping Bijia Wenti Diaocha Yanjiu Ziliaoji (Archive Materials for Studies of Industrial and Agricultural Commodity Prices)." The retail price information in these volumes is mostly culled from the account books of major stores in urban cities. The price statistics were published and circulated internally within the Chinese government and were intended for studying changes in relative prices between agriculture and industry between the 1930s the 1950s. Our retail prices used are the simple averages of 11 cities across China. For some of the services, such as transportation, communication and entertainment and so on, we use a multitude of sources such as local surveys, gazettes, and newspapers in both China and Japan. 
We employ three levels of consumption weights, denoted as I, II, and III in Appendix Table I. The consumption weights at the most aggregate level (level I) are adapted from Zhang Donggang (2001, pp.375-6). For second and third level weights, we use various local urban and rural surveys with shares weighted by with the urban and rural population figures. In the case of food consumption, we use urban consumption surveys for Shanghai, Tianjin, Nanjing, Wuxi and rural surveys for Beijing, Dingxian, Jiangning, Wuxing, Yuliangzhuang, Shangxiawuzhen, Xianghu and Wujiang.

The details of the matching and data sources for China-Japan PPP converter for consumption are presented in Appendix Table I with a matching of 51 items. Among the five consumption categories as listed in Table 1, Chinese housing expenses are the cheapest followed by food prices, which reflected the differential resource endowment conditions and stages of development. Another notable feature in Table 1 is the large discrepancy between the relative price levels of lighting and heat based on Chinese versus Japanese expenditure weights ( 0.58 versus 1.12 , also see Appendix Table I). The disparity reveals China's very low rates of electrification and relatively high cost of electric power in comparison to that of Japan, a powerful indicator of the differential degree of economic modernization between these two countries for the period. ${ }^{3}$ The overall relative price level of China is $73 \%$ that of Japan.

Insert Table 1

\section{PPP Converter for Private Consumption: Japan and the United States}

Price data for the U.S. in the mid-1930s are fairly abundant and reliable. For most of the food items, we rely on the Bureaus of Labor Statistics Bulletin No. 635 which provides weighted averages of retail prices in 51 cities. For the retail prices of fuel and utilities as well as wage rates, we use the Handbook of Labor Statistics (1941). Other sources include the Statistical Abstract of the United States (1938) for items such as clothing and utilities, and micro data from a comprehensive national urban household survey of consumer purchases in 1935-36. This household-based dataset can now be accessed through the ICPSR website hosted by the University of Michigan (http://www.icpsr.umich.edu).

3 Total electric power generated in Japan is more than 10 times of that in China (excluding Japanese-controlled Manchuria) in the 1930s. For total electric power generated in Japan and China in the 1930s, see Minami Ryoshin (1965) and Wang Qingyi (1988) respectively. 
The Historical Statistics of the U.S (bicentennial edition) provide us with the level I and II consumption expenditure weights. The detailed item weights in the mid-1930s are largely drawn from the cost of living survey in Bureau of Labor Statistics publication (Bulletin no. 699).

Details of the matching and source notes are presented in Appendix Table II. Table 2 summarizes our U.S-Japan binary matching of 53 items of goods and services altogether. It shows that around the mid-1930s the average cost of food in Japan was less than half of that in the United States. And the average cost of miscellaneous items in Japan, consisting mostly of services such as transportation, communication, education and entertainment, was only $36 \%$ of the U.S. level. In the case of lighting and heating which mostly consist of energy items, the Japanese price level was nearly identical to the U.S level. Housing expenses, which include the rent of land - a scarce factor in Japan - were about $63 \%$ of the U.S level. Appendix Table II suggests that Japanese nominal wage rates (for teachers, doctors and unskilled workers) were only about $10 \%$ the U.S. level based on mid-1930s exchange rates. The low wages and high energy and housing prices in Japan reflect differences in resource endowments and productivity levels during this period. ${ }^{4}$ The overall relative price level of Japan relative to the U.S. turns out to be $45 \%$ for the mid-1930s benchmark.

\section{Insert Table 2}

\section{PPP Converters for Private Consumption in East Asia}

As a cross-check, we make a direct PPP comparison between the U.S and China as shown in Appendix Table III. While the majority of price data for this comparison derived from those in Appendix Tables I and II, we also include additional price data from various sources. Overall, about 50 items of goods and services were matched, showing an overall Chinese price level at $32 \%$ of the U.S level. This ratio is nearly identical to the product of the China-Japan and Japan-US relative price levels (73\% x 45\%), thus satisfying the transitivity conditions of multilateral comparison. Table 3 summarizes the major categories of the China-US comparison, showing most Chinese price categories were only about $20 \%$ to $30 \%$ of the U.S level, except that of lighting and heating which was $80 \%$. This is consistent with the findings in Tables 2 and 3 .

Insert Table 3

\footnotetext{
${ }^{4}$ For the relatively low Japanese labor productivity levels relative to those of the U.S in the pre-WWII period based on a production sectoral level PPP comparison, see Dirk Pilat, 1994.
} 
The study by Fukao, Ma and Yuan (2006) matched 61 types of goods and services for the Japan-Korea comparison and 58 items for the Japan-Taiwan comparison. We combine the consumption PPPs from that study with our current result to convert the relative price levels of these two economies to the basis of the U.S by using Japan as the bridge country and applying the Fisher averages across the five upper level consumption weights. The final results for all the four East Asian economies are presented in Table 4 which gives the price levels of China, Taiwan, Korea and Japan relative to the United States at 32\%, 39\%, 43\%, and $45 \%$ respectively. Overall, price levels in East Asia were far lower in comparison with the U.S than within the region. Within East Asia, price levels within the Japanese colonial empire were closer to each other than with China, a fact consistent with Japan's colonial policy which forged a "free trade" zone within the empire by the 1930 s. $^{5}$

Insert Table 4

Table 4 also shows that overall price gaps for non-tradables between East Asia and the U.S are larger than those for tradables. This is a clear confirmation of the theoretical predictions of the productivity and factor proportion differential models that posit lower price levels for non-tradables in relatively underdeveloped countries. As is well known, using market exchange rates ignores the lower prices - particularly of nontradables - and thus underestimates the per capita income levels of less developed countries. The ranking of relative price levels presented in Table 4 is consistent with their per capita income rankings relative to the United States, which we will show later.

\section{PPP Converter for Private Investment and Government Expenditures: Japan and the United States}

Expenditure side GDP consists of private consumption, investment, government expenditure, and net exports. In this section, we follow the standard practice of the International Comparison Projects (ICP) to estimate the other two components of GDP, private investment and government expenditure. ${ }^{6}$ For China, relevant data for investment and government expenditure are unavailable. Liu and Yeh (1965, p. 68) indicated

\footnotetext{
${ }^{5}$ Taiwan and Korea became Japanese colonies in 1895 and 1910, respectively. By the 1910s, both Korea and Taiwan were set on a de-facto "Japanese yen exchange standard," - the two Central banks, the Bank of Korea and the Bank of Taiwan, issued their bank notes as circulating currency convertible to the Bank of Japan notes which served as the de-facto reserve currency. The currencies of Taiwan and Korea were also yen. The currencies of the three countries were convertible at the 1:1 exchange rate. By the 1930s, Taiwan, Korea and Japan had moved towards a free trade bloc protected by a common external tariff (Yamamoto 2000).

${ }^{6}$ As consistent with ICP and other international comparison studies, we do not separately estimate PPP for net exports partly because their share are likely to be small as a per cent of total GDP (especially for large countries) and partly because prices of traded goods are already included in other GDP components.
} 
that private consumption accounted for $91 \%$ of Chinese GDP during the benchmark period. We therefore feel reasonably comfortable to use our consumption PPP as a proxy for our GDP PPP in this study.

Due to data limitation, our estimates of PPP converters for private investment and government expenditures for Japan-U.S have to rely on somewhat crude assumptions. For estimation of PPP converter for private investment, we examine relative price levels of two main categories of private investment: equipment and construction investment in Japan and the United States. In the case of equipment investment, we use the relative price level calculated by Pilat (1993) for machinery and equipment for 1939. In the case of construction investment, we derive the price levels in Japan and the United States as weighted averages of price for construction materials and wages for construction laborers. The results are presented in Table 5 suggesting that the price level for private investment is $50 \%$ of the U.S. level, higher than the price level for private consumption.

\section{Insert Table 5}

For government expenditure for Japan and the U.S., we divide them into two categories: labor and material costs. Labor costs are measured as the ratio of the average income per government employee in Japan and U.S. Table 6 shows that the average Japanese government employees' compensation was only $7 \%$ of their U.S counterparts' in nominal terms. The second category, material cost, consists of government purchases from various sectors of the economy. Table 6 provides relative price levels and expenditure weights of ten materials. Their relative price level (of Japan over U.S) in weighted average turns out to be $55 \%$, higher than that for private consumption. This seems plausible as government purchase draws a substantial share from the investment sector of which Japanese price levels were closer to that in the U.S. Overall, thanks to the much lower remuneration paid to employees in Japan, the Japanese government expenditure price level overall was only $28 \%$ of that of the U.S.

\section{Insert Table 6}

Using the current-price PPP converters for private consumption, private investment, and government expenditures for Korea and Taiwan (relative to Japan) from Fukao, Ma, and Yuan (2006), and using Japan as the bridge country, we derive a full set of current-price PPP converters for GDP for the four East Asian economies for the mid-1930s, all converted to the base of the U.S, using the Fisher average. The detail of the calculation procedures and the results are reported in Table 7. 


\section{Real East Asian GDPs in 1934-36}

\section{$\underline{P P P}$ and Market Exchange Rates}

Table 8 presents the per capita GDP of the four East Asian economies in 1934-36 U.S dollars. The first data row shows GDP estimates for the different countries in 1934-36 current prices converted US dollars at market exchange rates. Not surprisingly, GDP at exchange rates gives very low income estimates for East Asia in the mid-1930s: Japan's per capita income was only 13\% of that of the U.S. while that of China was a mere $3.5 \%$ of the U.S. level. The second row of Table 8 presents the price levels of the four East Asian economies relative to the U.S.

\section{Insert Table 8}

Dividing the exchange rate-based per capita income estimates by the relative price levels, we can derive our 1934-36 benchmark PPP adjusted estimates, presented in the third row of Table 8. In comparison with the exchange rate conversion, our PPP converter more than doubles the per capita income of Japan and Korea Taiwan and triples the per capita income of Taiwan and China. Undoubtedly, the PPP conversion is a major correction of the downward exchange rate bias.

Existing studies on PPP for the pre-war East Asia are few. The study by Colin Clark published in 1940 (p. 41) gave Japanese per capita income in 1925-34 at about 26\% of the U.S level, closer to our PPP result than that of exchange rate conversion. However, since both the GDP estimates and price levels used by Clark were long outdated, his study should not be viewed as a direct confirmation of our estimates. The more systematic Japan-U.S PPP study was carried out by Pilat $(1993,1994)$ with 1939 as the benchmark year and using an output PPP approach by matching the unit value ratios of comparable goods and services. His study (Pilat 1994, p.24) gives a price level for the overall Japanese economy relative to that of the U.S at $60.7 \%$, higher than our $42 \%$ figure based on the expenditure approach. The discrepancy is not surprising as the output based PPP matching weights more heavily towards the tradable items whose prices are likely to be closer across countries.

A crude attempt at calculating purchasing power parities for China and the U.S was done by Liu Tachung, a pioneer in the reconstruction of the 1931-36 Chinese per capita GDP. His market exchange rate 
conversion, like ours, gave the 1931-36 Chinese per capita GDP at 3.8\% of the U.S level (Liu 1947, p. 72). To correct for the possible downward bias of 1930s Chinese per capita incomes, he compared Chinese and American prices for five categories of agricultural crops and arrived at a Chinese price level of $63 \%$ of the U.S. level (p.73). Liu's current-price PPP conversion based on these relative price levels gave the 1931-36 Chinese per capita GDP at 5.7\% of the U.S level (Liu 1947, p. 76). But recognizing that the price level differences in agricultural products were possibly the least of the cause of the downward bias, Liu went on to adjust for other structural differences between the U.S and Chinese economies, a concept that was not clearly spelled out in his study. His final adjustment raised the Chinese per capita income to $9 \%$ of the U.S level, a level approaching but still lower than our PPP estimate for China relative to the U.S as shown in Table 8.

\section{Current-Price PPP versus 1990 Backward Projection}

It is very instructive to compare our estimates with the massive dataset compiled by Angus Maddison. In Figure 1, we follow Maddison and convert all per capita GDP estimates into 1990 dollars. Maddison's latest 2003 series provide a back-projected U.S per capita GDP for 1934-36 of 5,590 dollar in 1990 prices. We use this U.S. figure as the base and apply our relative price levels to derive the per capita incomes of the four East Asian economies in 1990 dollars. Figure 1 compares our 1934-36 benchmark PPP estimates with Maddison's 1990 back-projected estimates, both in 1990 prices.

\section{Insert Figure 1}

Figure 1 shows that the deviation between our estimate and Maddison's for Taiwan and China are relatively small. However, his Korean estimate is nearly twice our level and his Japanese figure is $22 \%$ higher. Maddison's Japanese per capita income of 2,154 dollars (in 1990 dollars) would make the Japanese level at about $39 \%$ of the U.S level for 1934-36 in comparison with our estimate of 1,760 dollars, at $32 \%$ of the U.S level. Likewise, while the per capita income gap between China and Japan according to Maddison is about 1 to 4, our current price PPP estimate reveals it to be about 1 to 3 for the mid-1930s period. Similar discrepancies in per capita incomes also hold true for Japan versus Taiwan and Korea.

Maddison's upward adjustment of Japanese per capita income from 13\% (as implied by exchange rate conversion) to $39 \%$ of the U.S. level would imply a Japanese price level at only about $36 \%$ of the U.S level, lower than the $43 \%$ derived from our study. Similarly, his adjustment of Korean per capita income from 5.1\% 
to $22 \%$ of the U.S level would indicate a Korean price level at only $23 \%$ of the U.S level, only about half of the $41 \%$ level derived from our study.

\section{Robustness Checks and Sensitive Test}

Here we carry out some robustness checks on our PPP estimate. One potential source of error in our PPP comparison is the use of urban price only for these five economies with differential urban-rural shares of population. While urban population shares in the U.S, Japan and Taiwan are roughly comparable, at 56,54 and 48 percent respectively, the corresponding shares for Korea and China are much lower at 25 percent only. Thus, purely urban-price-based price matching would over-estimate the relative price levels of the more ruralbased economies of Korea and China. A back-of-the-envelope calculation would show that for two economies with identical urban-rural price gap, national price level (weighted average of urban and rural prices) in a country with $25 \%$ urbanization would be $4.5 \%$ lower than a country with $50 \%$ share of urban population. On the other hand, this downward bias in price levels can also be potentially offset by the relatively lower quality of products and services in poorer and rural-based economies. Thus, our current study makes no adjustment in price level with respect to differential urban-rural population shares. ${ }^{9}$

A second issue is the coverage of our PPP study. With 50-60 items for private consumption and 15-20 items for investment and government expenditure categories, our study is superior to other known PPP works for the pre-WWII period. However, it is still relatively crude by the standard of the large-scale Post-WWII ICP exercise that employed 153 categories with hundreds or thousands of individual item prices (Kravis et al, 1982). To test the possible biases of the limited coverage, we match directly the individual categories items of our 1934-36 benchmark with the 153 categories in the 1967 round of ICP study, the earliest year available for Japan-US comparison (see Kravis et al 1975, pp.257-261). Altogether 46 out of 153 categories in 1967 can be matched. ${ }^{10}$ The 1967 shares of these 46 categories amounted to $36 \%$ with Japanese weight and 47\% with US weight. Our PPP calculation (using fisher average) based on these 46 categories alone yields a Japanese price

\footnotetext{
${ }^{8}$ For urban shares in US, Japan, Taiwan, Korea and China, see Historical Statistics, Part I, p.11, Hundred-Year Statistics, p.14, M\&U, pp. 263 and 268, Buck, p.362.

${ }^{9}$ For urban-rural price gap in UK and US, see Ward and Devereux, p.831.

10 The 153 categories for 1967 can be found in Kravis et al, 1975, pp. 257-9. The matched 46 categories out of the 153 categories in 1967 are categories $1-3,7,9-10,13-15,17,21-23,28,30,33,37,38,40,48,52,54,55,58,72,75,83,85-$ $87,90,97-100,104-106,125,136,137,149-153$.
} 
level at $58 \%$ of the U.S, lower than the $63 \%$ level derived from the 153 categories in 1967 . This $5 \%$ difference can be easily explained by the fact that most of the unmatched categories are new and modern products that appeared in the post-WWII period, whose relative price levels between Japan and U.S were smaller than average. In view of the above, we believe that, were a full-scale ICP type of PPP study conducted for the 193435 benchmark, the price gap between the ideal ICP study and our study would not be large, certainly below the $5 \%$ difference.

Finally, we test to see how sensitive our PPP price level to the price of any individual item. We perform an experiment on our China-Japan data sets in Appendix Table II by dropping an individual item whose weight redistributed to all other items in the data set to re-compute the Fisher-PPP converter. We find that the overall deviation of the recomputed PPPs (with one item excluded each time) from the full-sample based PPP is very small (a standard deviation of 0.0065 for the mean China-Japan relative price level of 0.73 ). These tests give us some confidence that the margin of errors in our estimate are within reasonable bounds and our PPP result is robust even judged by the stringent Post-WWII ICP standard.

Table 9 presents a comprehensive comparison of the relative GDP price levels derived from our study against those in other PPP benchmark studies across different periods as well as Maddison's back-projection. The table shows clearly the implicit relative price levels in Maddison's back-projected estimates for Japan and Korea - the two countries where our per capita GDP estimates differ most as shown in figure 1 - seemed implausibly low. Surprisingly, even his own output based PPP studies on Japan and Korea for 1965 when their relative per capita income levels were not that far apart from the 1934-36 period showed relative price levels and per capita GDP far closer to our study than his own back-projected estimate.

Insert Table 9

\section{Backward Projection: Theoretical and Empirical Issues}

Our finding of a significant discrepancy between GDP figures based on current price PPP and back-projected PPP have long been confirmed by various existing research such as the numerous rounds of post-War ICP 
studies (Kravis, Heston and Summers 1982, Heston and Summers 1993, Maddison 1998). By comparing past ICP results of every five years from 1970 and backward projected per capita GDP based on 1990 benchmark PPP, their studies reveal substantial gaps between the two values for many countries. Recent studies on longterm historical data of U.S and Europe also confirmed similar discrepancies (Ward and Devereux 2003, 2005). We see two major sources of errors arising out of back-projection from the 1990 benchmark. First is likely to occur in the making of a long-term real GDP series which consist of disparate volume series often reconstructed with varying quality, definitions and benchmarks. The second is the index number bias inherent in the back-projection procedure which cast the later period price or quantity weights to the current period ones. Below, we turn to these two issues.

\section{The Making of Real GDP Series in East Asia and US}

Long-term domestic real GDP series used for a period of 60 years between 1930 and 1990 rarely come from a single continuous series. Instead, disparate series with multiple benchmarks or varying definitions, quality and coverage were often "patched together." For example, the coverage and definition of GDP statistics have been revised in the transition from the 1968 SNA to the 1993 SNA. The linking procedure of using the late-year benchmark as adopted by Maddison could end up shifting the value of the current price nominal GDP in the earlier period. Although this type of linking is one non-rigorous way of updating the past series of real GDP from the old definition to the new definition, it could potentially lead to discrepancy between back-projected and current price estimates. Below, we trace Maddison's linking procedure for the five economies under study here.

We first examine Taiwan and China where the discrepancies between current and back-projected estimates are the smallest. The Taiwan real GDP series used by Maddison is the most consistent, based entirely on the 1912-1990 series meticulously reconstructed by Mizoguchi and others and uses 1960 price as the benchmark. Maddison's Taiwan 1990 benchmark PPP came from the Penn World Table, which in turn was updated from the 1985 benchmark PPP from Yotopoulos and Lin (1993) (See Maddison, 2003, p. 153, Fukao et al, 2006). Maddison's Chinese GDP series is presented in detail in his 1998 OECD publication. As is wellknown, both the level and trend of Chinese GDP in the post-WWII Communist period are highly controversial due to major differences in definitions and coverage. Maddison's linking of Chinese GDP series between the 1930s and 1950s relied on the careful work of Liu and Yeh (1965) and others. In fact, Maddison used the 
1930s GDP to benchmark the real GDP level for the Communist period (pp. 149-155). Like for Taiwan, Maddison's 1990 benchmark PPP is updated from 1986 benchmark PPP estimated by Ren Ruoen (Maddison 1998, p.153-4).

In contrast, Maddison's linking of Korea real GDP seems the most problematic. There are no consistent GDP series for Korea between 1938 and 1953. Maddison linked the colonial series and post-WWII series by combining a host of disparate independent estimates added with assumptions about the split of territories and population between North and South Korea in the post-war period (Maddison 2003, p. 153). Although further investigation is necessary, we suspect the large margin of errors inherent in Maddison's linking could give rise to the striking discrepancy between the current price and back-projected per capita income estimate for 193436 Korea (see Fukao et al 2006 for details).

Finally, we turn to examine the linking of US and Japanese real GDP series. The U.S real GDP series is the most straightforward as Maddison's entire series from 1929 onward is from the official Department of Commerce, Bureau of Economic Analysis (BEA) statistics from which we also derive the mid-1930s benchmark current price estimate (Maddison 2003, p.79-80). Discrepancies, if any, between the old and new versions of the BEA series are mostly for the post-War period rather than the 1930s figures and they are usually in the range of $5-6 \%{ }^{14}$

For Japan, Maddison used the same Ohkawa and Shinohara GDP series for the pre-War period as we did. However, the series ended in 1940 and the post-War series began only after 1952. Maddison's most recent study filled the War period gap by utilizing an independent study on War time GDP by Mizoguchi and Nojima (1996). We trace and compare the nominal GDP figures for the three different linking periods at 1940, 1952 and 1960. We find the discrepancies between the nominal figures in different series at each linking periods are relatively minor, and overall the linking procedure by Maddison might lead to a 5.45\% upward revision of the original Ohkawa and Shinohara series for the pre-War period. ${ }^{15}$ Since both the Japanese and US series seem to

\footnotetext{
${ }^{14}$ See Historical Statistics vol.1, p.224 for the old version and http://www.bea.doc.gov/bea/dn/gdplev.xls for the new version).

${ }^{15}$ The nominal GDP figures for 1940 used by Mizoguchi and Nojima come from Japanese government publication (Keizai Shingi-cho (1953) and Keizai Kikaku-cho (1963)). It is equal to $99 \%$ of the nominal GDP figures in the Ohkawa and Shinohara series at 1940. Nominal GDP figures used by Maddison to link 1952 and 1960 come from the OECD National Income Statistics (1976 and 1999) are both equal to about 1.03 of the old series. Overall, the linking of the three series in total revised upward the level of real GDP series by $5.45 \%$.
} 
be raised by about 5-6\% in this process, updating the real GDP series of both U.S and Japan based on the late series is not likely to impact greatly the levels of their nominal GDP in the 1930s.

To sum up, except for Korea, Maddison's linking procedure has been reasonably consistent for the other four economies in this study. Therefore, to explain Maddison's 22\% upward bias for Japanese per capita income estimate, we need to turn beyond the linking procedure and examine the index number problem bias in back-projection.

\section{Backward Projection Bias: an Index Number Formulation}

One difference between our PPP study and the ICP based studies is the use of PPP Fisher average versus the multilaterial Geary Khamis (GK) method.. It is well-known that the GK method yields lower PPP and thus higher PPP-adjusted real GDP estimates of lower income countries than the Fisher average. ${ }^{16}$ However, according to Maddison's survey (1996, Table C-6, p.172), the Fisher-based PPP only exceeds the GK ones by about $5-6 \%$ in 1990 . This ratio is far too small to explain Maddison's $22 \%$ deviation from our current price estimate for Japan. This ratio was also used by Maddison to update the original Fisher-based PPP Taiwan (1985 benchmark) and China (1986 benchmark) into GK index. For our index number formulation, we present everything in terms of GK international price.

We express the 1990 benchmark backward projected real per capita GDP in benchmark year $t$ ( $t$ is 1934-36 in this study) as in equation (1):

$$
y_{i}^{E}(t, 90)=\frac{\mathbf{p}^{i}(t)^{\prime} \mathbf{q}^{i}(t)}{\mathbf{p}^{i}(t)^{\prime} \mathbf{q}^{i}(90)} \mathbf{p}^{G}(90)^{\prime} \mathbf{q}^{i}(90)
$$

where $\boldsymbol{p}^{i}(t)$ denotes a column price vector for commodities (or services) of types 1 through $N$ in country $i$ at time $t$, and $\boldsymbol{p}^{G}(90)$ denotes the column vector of the reference price [Geary-Khamis (GK)]international price] , for year 1990. Similarly, $\boldsymbol{q}^{i}(t)$ and $\boldsymbol{q}^{i}(90)$ are the corresponding vectors of country $i$ 's real per-capita net valueadded.

The first term in the right-hand side of the above equation is the ratio of country $i$ 's real GDP at time $t$ over that in 1990 measured in year $t$ price. The second term is country $i$ 's 1990 real GDP in 1990 GK price. The product of the two terms gives us $y_{i}^{E}(t, 90)$, the Maddison style 1990 back-projected real GDP of country $i$ at

\footnotetext{
16 The over-estimation of per capita GDP in low income countries and thus the under-estimation of global inequality due to the use GK method is explored in detail in Dowrick and Akmal 2005.
} 
time $t$, with the superscript $E$ stands for back-projection or extrapolation. These estimates are equivalent to the "Maddison's estimate" for East Asia in figures 1.

Our 1934-36 benchmark GDP in current U.S dollars as shown in row 3 of Table 8 can be formally written as $y_{i}^{C}(t)=\frac{\mathbf{p}^{G}(t)^{\prime} \mathbf{q}^{i}(t)}{\mathbf{p}^{G}(t)^{\prime} \mathbf{q}^{U S}(t)} \times \mathbf{p}^{U S}(t)^{\prime} \mathbf{q}^{U S}(t)$, with superscript $C$, stands for $c$ urrent price. To derive our 1934-36 East Asian GDP in 1990 dollars (shown as "Our estimate" in figure 1), we first divide our current price per capita income estimate, $y_{i}^{C}(t, 90)$, by that of the US, $y_{U S}{ }^{C}(t)=\mathbf{p}^{U S}(t)^{\prime} \mathbf{q}^{U S}(t)$, and then multiply Maddison's 1990 back-projected US estimate, $y_{i}^{E}(t, 90)$. With some cancellation, the whole term is spelled out in equation (2) as follows:

$$
y_{i}^{C}(t) \div y_{U S}^{C}(t) \times y_{U S}^{E}(t, 90)=\frac{\mathbf{p}^{G}(t)^{\prime} \mathbf{q}^{i}(t)}{\mathbf{p}^{G}(t)^{\prime} \mathbf{q}^{U S}(t)} \times \frac{\mathbf{p}^{U S}(t)^{\prime} \mathbf{q}^{U S}(t)}{\mathbf{p}^{U S}(t)^{\prime} \mathbf{q}^{U S}(90)} \times \mathbf{p}^{G}(90)^{\prime} \mathbf{q}^{U S}(90)
$$

Clearly, since equations (1) and (2) are based on different index number formulaes, it can only be pure coicidence that two figures are equal. To analyze the deviation of these two estimates, we conduct a logdecomposition of the ratio of equations (1) over (2). Re-arranging the terms, we express the full logdecomposition identity in equation (3) as follows:

$$
\begin{aligned}
& \left\{\ln \left(y_{i}^{E}(t, 90)\right)-\ln \left(y_{U S}^{E}(t, 90)\right)\right\}-\left\{\ln \left(y_{i}^{C}(t)\right)-\ln \left(y_{U S}^{C}(t)\right)\right\} \\
& =\left\{\ln \left(\frac{\mathbf{p}^{G}(t)^{\prime} \mathbf{q}^{i}(90)}{\mathbf{p}^{G}(t)^{\prime} \mathbf{q}^{i}(t)}\right)-\ln \left(\frac{\mathbf{p}^{i}(t)^{\prime} \mathbf{q}^{i}(90)}{\mathbf{p}^{i}(t)^{\prime} \mathbf{q}^{i}(t)}\right)\right\}+\left\{\ln \left(\frac{\mathbf{p}^{G}(90)^{\prime} \mathbf{q}^{i}(90)}{\mathbf{p}^{G}(t)^{\prime} \mathbf{q}^{i}(90)}\right)-\ln \left(\frac{\mathbf{p}^{G}(90)^{\prime} \mathbf{q}^{U S}(90)}{\mathbf{p}^{G}(t)^{\prime} \mathbf{q}^{U S}(90)}\right)\right\} \\
& \\
& -\left\{\ln \left(\frac{\mathbf{p}^{G}(t)^{\prime} \mathbf{q}^{U S}(90)}{\mathbf{p}^{G}(t)^{\prime} \mathbf{q}^{U S}(t)}\right)-\ln \left(\frac{\mathbf{p}^{U S}(t)^{\prime} \mathbf{q}^{U S}(90)}{\mathbf{p}^{U S}(t)^{\prime} \mathbf{q}^{U S}(t)}\right)\right\}
\end{aligned}
$$

Equation (3), as cumbersome as it appears, has nice interpretative properties: a positive (or negative) value implies an over-estimate (or under-estimate) of the $t$ period per capita income using the 1990 back-projection method. We summarize the first two terms in equation (3) as "weight inconsistency" effect also defined by Szilágyi (1984). It is the log-difference between country $i$ 's real GDP growth rates from $t$ to 1990 measured using the $t$ period GK price and that based on the $t$ period domestic price. This weight inconsistency effect, similar to the so-called "Gerschenkenron effect," stems from the divergence in domestic real GDP growth rates 
derived from the use of international price versus domestic price of the $t$ period. As partly shown in our matched price items for the mid-1930s, prices in East Asia relative to the U.S tended to be relatively lower in the primary and service sectors but higher in manufacturing and industrial goods. As international price at time $t$ assigns relatively lower weights than domestic price to the expanding manufacturing sector but higher weights to the slow-growing primary sector and expanding service sectors, real GDP growth rate measured using the 1930s international price would be smaller than that using domestic price. Holding other things constant, the weight-inconsistency effect in our case is likely to be negative, implying back-projection under-estimate country $i$ 's real GDP at time $t$.

The second component, captured by the next two terms, is bracketed as "terms of trade effect" in Equation (3). Independently, the two terms are indices of international GK price between $t$ and 1990 for country $i$ and US, each weighted by their respective GDPs in 1990. They take a positive (or negative) value if international price from year $t$ to 1990 rises (or falls) for their output at 1990. With certain assumptions, each one of these two indices is equivalent to a country's Paasche terms of trade index. The log-difference between these two terms, defined as the "terms of trade" effect, indicates if improvement (or deterioration) in country $i$ 's Paasche terms of trade is greater than that for the U.S, then backward projection will over-estimate (or underestimate) country $i$ 's output at time $t$.

Intuitively, this can be understood by the following hypothetical example. Suppose there are two open economies $A$ and $B$. Country $A$ is a producer of primary goods and country $B$ is a producer of manufacturing goods. Suppose two countries' total GDP are equal measured at the international prices in 1930. By 1990, both countries have doubled their output but international prices for primary goods have also doubled while those for manufacturing goods have remained constant. This would imply country $A$ 's GDP is twice that of country $B$ based on 1990 price due to the terms of trade improvement. If we project backward based on the 1990 international price, we will overestimate the relative standing of country $A$ over $B$ in comparison to that based on the 1930 international price. Since the East Asian economies are more similar to country $A$ type than is the U.S, our conjecture is that back-projection leads to over-estimation biases of their per capita incomes in the 1930s.

The final two un-bracketed terms in equation (3) is the log-difference between two US quantity indices measured by GK price and US prices respectively at time $t$. Since our PPP study for 1934-36 benchmark is 
based on the US as the base country, the difference between US and GK prices in 1934-36 is trivial and can be ignored.

Our index number formulation reveals the bias effects of weight-inconsistency and terms of trade are in fact opposite in direction. This leaves both the direction and magnitude of bias dependent upon the relative strength of these mutually offsetting factors. This important insight may explain the lack of any systematic direction in biases as revealed in this study as well as the post-WWII ICP. Ideally, one could empirically test the back-projection bias given the availability of long-term data on economic structure and terms of trade. Unfortunately, such empirical test faces several difficulties. As indicated earlier, long-term real GDP series themselves are rarely consistently back-projected from the 1990 benchmark according to our idealized index number formulation. Often, GDP series with multiple benchmarks or varying definitions are linked together, possibly to compound the existing biases, making it extremely complicated, if not impossible, to disentangle.

In Appendix A, we present a preliminary test on the impact of terms of trade (TOT) effect based on our index number formulation. We first test the statistical relationship between TOT and back-projection biases based on the ICP data for the Post-War period. Our regression does confirm a statistical significant coefficient with the right sign. We then test this relationship between Japan and US between 1935 and 1990 . We find similar confirmation of this relationship between TOT and back-projection biases. However, our preliminary calculation shows that the magnitude of the $3 \%$ of the upward biases can be accounted for by this TOT improvement in Japan relative to the US, clearly a small fraction in relation to the $22 \%$ overestimate we found in this study. However, this test is highly preliminary due to various data problems illustrated in the Appendix A. Clearly, much more research is needed. Meanwhile, we believe that the reconstruction of current price benchmark PPP study remains as the most important cross-check on back-projected estimates.

\section{Implications and Summary}

Pre-war GDP estimates for Japan and East Asia based on back-projection have been widely cited in major textbooks and academic publications on economic growth. Our new current-price based estimates thus carry large implications. Firstly, they realigned the 1930s per capita income ranking and gap among the four East Asian economies studied. Chinese per capita income in the 1930 s were $35 \%$ of the Japanese level according to our estimate, compared with Maddison's 26\%. This ratio for the Japanese colony of Taiwan is $72 \%$, much 
higher than Maddison's 56\%. Meanwhile, our estimates show that Taiwanese per capita income is $82 \%$ higher than Korea whereas Maddison shows they are comparable (see Figure 1).

Furthermore, if we insert our estimate of 1934-35 Japanese per capita estimate of 1,760 dollars (in 1990 prices) in place of Maddison's 2,154 figure in the Maddison dataset, it would show a Japanese per capita income lower than almost all other Western European countries, including Spain, Italy and Greece, only comparable to USSR, marginally higher that of Malaysia or the Philippines for that period. These intriguing findings seem to point to the need for a more comprehensive research on pre-War PPP for other countries as well.

If we back-cast our mid-1930s PPP adjusted income estimate sheds further light on Japan's initial conditions in the early Meiji period. For example, projecting backward from the level of 1,760 dollars (in 1990 prices) in the mid-1930s - rather than Maddison's 2,154 dollars (in 1990 prices) - gives an 1880s Japanese per capita income of about 600 dollars (in 1990 prices), only marginally higher than those in China and India but lower than in Philippines and Thailand (see Maddison 2003, p.180). In other words, on the eve of the first wave of industrialization in the 1880s, the Japanese economy was near subsistence, no richer than those of its Asian neighbors, whom Japan was to overtake or even colonize in the following few decades.

This is clearly quite a reassessment of prevailing view on both the initial conditions and the dynamics of long-term economic growth for Japan and Asia in general. We have reason to believe that our result is much more consistent with available information on economic structures, consumption patterns and historical realities. Recent studies based on the comparison of real wages seem to lend tentative support to this reassessment. For example, Bassino and Ma (2005) and Allen et al. (2005) show that Japanese real wages in the $18^{\text {th }}$ century were close to those in China and low-income European countries such as Italy. Real wages only consistently rose above the Chinese level after the 1890s and reached more than twice China's level by the 1920s, a result consistent with the per capita GDP differences indicated in this PPP study for the mid-1930s. Studies by Bassino and Eng (2002) and Bassino (2005) also reveal that daily nominal wages for unskilled laborers and carpenters in Tokyo in 1935 were not much higher than those in Bangkok, Singapore, or Penang in British Malaya. As consumer price levels, particularly food prices, were much lower in those Southeast Asian cities, their studies suggest that real wages in Tokyo were lower than in those cities. 
In this regard, the respectable Japanese economic growth in the pre-WWII period should be deemed more as keeping-up with the world income leaders but catching-up (or even overtaking) with the resource rich Southeast Asia. Japanese and subsequently Taiwanese and Korean economic convergence with the world income leaders is truly a post-war phenomenon. This is particularly striking if one compares the pre- and postwar income gaps within East Asia. Income differentials of Japan, Taiwan, Korea versus China in the 1980s were multiples of those in the 1930s. In this regard, China's rapid economic growth since the 1980s, particularly in some of her coastal regions, is partly a making-up for her missed opportunities.

Of course, the big question is: why was it Japan - rather than Malaysia or Thailand - that caught up so quickly in the post-War period despite their possibly common starting points? We can offer some conjectures. Bassino (2005)'s wage data shows that the skill premium for carpenters vis-à-vis unskilled laborers in Tokyo was smaller than in any of the Southeast Asian cities, indicating the existence of a large pool of skilled workers in Japan in comparison with Southeast Asia. A recent study by Godo and Hayami (2003) reveal that in the 1930 s, average years of schooling in Japan were already over $60 \%$ of the U.S. level despite the much greater lag in per capita income. Japan then already had some of the world's most dynamic industries, a sizable entrepreneurial class, a competent bureaucracy and, of course, a nation state. Was Japan already on a course of convergence in the pre-war era but was thrown off course by the War? This PPP study provides new answers and raises new questions.

In sum, our study provides a set of pre-war benchmark PPP converters that allow us to carry out comparisons of income, consumption, and other monetary indicators for East Asia in a global context. Our prewar PPP converters confirm that market exchange rate conversion consistently under-estimated per capita incomes of East Asia. They also reveal biases associated with the 1990 backward projection method. Our preliminary theoretical and empirical analysis pointed out the direction of such bias and set out a framework for future research which will enable us to quantify the magnitude of this bias and to eventually "consistentize" our new levels with growth trend in the long-term GDP series for East Asia and beyond.

Our finding that Japanese per capita income in the mid-1930s or the entire pre-war period was lower than widely believed is a major revision of our existing interpretation of long-term economic growth in Japan and East Asia. It may also have further reverberations on our interpretation of the determinants of long-term 
economic growth. The fact that that Japan, or East Asia in general, were historically very poor, is perhaps a message of blessing for developing countries today: initial poverty itself is no curse to a nation's aspirations for prosperity.

\section{References}

Allen, Bob, Jean-Pascal Bassino, Debin Ma, Christine Moll-Murata, and Jan Luiten van Zanden (2005) "Wages, Prices and Living Standards in China, Japan and Europe" downloadable at http://gpih.ucdavis.edu/Papers.htm.

Balassa, Bela (1964) “The Purchasing Power Parity Doctrine: A Reappraisal," Journal of Political Economy, vol. 72, pp. 584-596.

Bank of Japan, (1966), Hundred-Year Statistics of the Japanese Economy. Tokyo.

Bassino, Jean-Pascal, and Pierre van der Eng (2002) "Economic Divergence in East Asia: New Benchmark Estimates of Levels of Wages and GDP, 1913-1970," paper presented at the XIII Economic History Congress, July 22-26, 2002, Buenos Aires.

Bassino, Jean-Pascal, and Debin Ma (2005) "Japanese Wages for Unskilled Laborers in 1730-1910: an International Perspective," forthcoming in Research in Economic History.

Bassino, Jean-Pascal (2005) "How Poor Was Asia before the Industrialization?" unpublished manuscript, Tokyo: Maison Franco- Japonaise.

Buck, John (1937) Land utilization in China : a study of 16,786 farms in 168 localities, and 38,256 farm families in twenty-two provinces in China, 1929-1933 Nanking : University of Nanking.

Bureau of the Census (1939), Census of Manufactures, 1939, Washington D.C.: Bureau of the Census.

Clark, Conlin (1940, 1957) Conditions of Economic Progress, London: St. Martins’s Press.

Emi, Koichi and Shionoya, Yuichi (1966) Estimates of Long-Term Economic Statistics of Japan since 1868 (LTES) vol. 7, Government Expenditure, Tokyo: Toyo Keizai Shinposha.

Emi, Koichi (1971) Estimates of Long-Term Economic Statistics of Japan since 1868 (LTES) vol. 4, Capital Formation. Tokyo: Toyo Keizai Shinposha.

Fukao, K., Ma, D., and Yuan, T. (2006) "International Comparison in Historical Perspective: Reconstructing the 1934-36 Benchmark Purchasing Power Parity for Japan, Korea and Taiwan," Volume 43, Issue 2 April 2006, Explorations in Economic History.

Godo, Yoshihisa, and Yujiro Hayami (2002) "Catching Up in Education in the Economic Catch-up of Japan with the United States, 1890-1990" Economic Development and Cultural Change, vol. 50, no. 4, pp. 961-78.

Heston, Alan and Robert Summers (1993) "What Can Be Learned from Successive ICP Benchmark Estimates?" A. Szirmai, B. Van Ark, and D. Pilat eds. Explaining Economic Growth, Amsterdam: North Holland.

Hsiao, Liang-lin (1974) China's Foreign Trade Statistics, 1864-1949. Cambridge: Harvard University Press. 
Kravis, Irving B., Alan Heston, and Robert Summers (1975) A System of International Comparisons of Gross Product and Purchasing Power, Baltimore: Johns Hopkins University Press.

Kravis, Irving B., Alan Heston, and Robert Summers (1978) International Comparisons of Real Product and Purchasing Power, Baltimore: Johns Hopkins University Press.

Kravis, Irving B., Alan Heston, and Robert Summers (1982) World Product and Income, International Comparisons of Real Gross Product,. Baltimore: Johns Hopkins University Press.

Liu, Ta-chung (1946) China's National Income 1931-36, An Exploratory Study, Washington, D.C.: the Brookings Institution.

Liu, Ta-chung, and Kung-chia Yeh (1965) The Economy of the Chinese Mainland: National Income and Economic Development, 1933-1959, Princeton, New Jersey, Princeton University Press, 1965.

Maddison, Angus (1995) Monitoring the World Economy 1820-1992, Paris, France: OECD.

(1998) Chinese Economic Performance in the Long Run, Paris, France: OECD.

(2001) The World Economy: a Millennial Perspective, Paris, France: OECD.

(2003) The World Economy: Historical Statistics, Paris, France: OECD.

Minami, Ryoshin (1965). Railroads And Electric Utilities. Kazushi Ohkawa and others eds. Estimates of LongTerm Economic Statistics of Japan since 1868 (LTES) vol. 12. Tokyo: Toyo Keizai Shinposha.

Ministry of Commerce and Industry, Statistics Department, Japanese Government (1938) Koujyou Toukei (Factory Statistics) 1938.

Ministry of Industry, National Government (1934-36), Zhongguo Jinji Nianjian (China Economic Annals). Shanghai: Commercial Press.

Ministry of Railroad, Transportation Bureau, International Department (1937), Sekai Katsukoku Tetsudo Tokei (Rail Statistics of the World), Tokyo: 1937.

Ministry of Railroad (1975) Tetsudo Tokei (Rail Statistics). Tokyo.

Mizoguchi, Toshiyuki (1975) Taiwan, Chosen no Keizai Seicho: Bukka Tokei wo Chushin to shite (Economic Growth of Taiwan and Korea: a Study of Prices). Tokyo: Iwanami Shoten.

Mizoguchi, Toshiyuki, and Umemura, Mataji, eds. (1988), Kyu Nihon Shokuminchi Keizai Tokei: Suikei to Bunseki (Basic Economic Statistics of Former Japanese Colonies 1895-1938), Tokyo: Toyo Keizai Shinposha.

Mizoguchi, Toshiyuki, and Nojima, Noriyuki (1993) "194-55 Nen ni Okeru Kokumin Keizai Keisan no Ginmi (Nominal and Real GDP of Japan: 1940-55)," Nippon Tokei Gakkaishi (Journal of the Japan Statistical Society). Vol. 23, No. 1, pp. 91-107.

Mizoguchi, Toshiyuki, and Nojima, Noriyuki (1996) "Taiwan, Kankoku no Kokumin Keizai Keisan Choki Keiretsu no Suikei" (Estimation of the Long Term National Accounts of Taiwan and Korea) Asian Historical Economic Statistics Project Discussion Paper: R96-6, Tokyo: Institute of Economic Research, Hitotsubashi University.

OECD, Department of Economics and Statistics, OECD (1976) National Accounts of OECD Countries, OECD. 
OECD, Department of Economics and Statistics, OECD (1999) National Accounts of OECD Countries, OECD.

Keizai Kikaku-cho (Economic Planning Agency), Japanese Government (1963) Showa 37 Nendo Kokumin Shotoku Hakusho (White Paper on National Income 1962 C.Y.), Tokyo: Printing Office, Ministry of Finance.

Keizai Shingi-cho (Economic Counsel Board) Japanese Government (1953) Showa 27 Rekinen Kokumin Shotoku Hokoku (Report on National Income Statistics 1952 C.Y.) , Tokyo: Keizai Shingi-cho (Economic Counsel Board).

Keizai Shingi-cho, Chosabu Tokeika (Stiatistical Division, Economic Counsel Board) Japanese Government (1953) Senzen Kijun Shohi Suijun-Tokyo SanSyutsu Hoho 1 Tukei Siryo No.78. (Pre-War Standard Consumption Level - Method of Calculation for Tokyo (1), Statistical Materials No. 78), Tokyo: Keizai Shingi-cho (Economic Counsel Board).

Ohkawa, Kiyoshi, and Shinohara Miyohei (1979) Patterns of Japanese Development: A Quantitative Appraisal, New Haven, CT.: Yale University Press.

Ou, Baosan, ed. (1947) Zhongguo Guomin Soude (National Income of China), vols. 1 and 2, Shanghai: Zhonghua sujui.

Perkins, Dwight H. (1975) "Growth and Changing Structure of China's Twentieth-Century Economy," in Dwight H. Perkins, ed., China's Modern Economy in Historical Perspective. Stanford: Stanford University Press.

Pilat, Dirk (1994) The Economics of Rapid Growth: The Experience of Japan and Korea, Aldershot UK and Brookfield US: Edward Elgar.

Samuelson, Paul (1964) "Theoretical Notes on Trade Problems," Review of Economics and Statistics, vol. 46: pp. 145-154.

Szilagyi, Gyorgy (1984) "Updating Procedures of International Comparisons Results" Review of Income and Wealth, vol. 30, pp. 153-65.

Summers, Robert, and Alan Heston (1991) "The Penn World Table (Mark 5): An Expanded Set of International Comparisons, 1950-88,"Quarterly Journal of Economics, vol. 106, no. 2, pp. 327-68.

U.S. Department of Labor, Bureau of Labor Statistics, Department of Agriculture. Bureau of Home Economics Micro data of Study of Consumer Purchases in the United States, 1935-1936, ICPSR 8908, http://www.icpsr.umich.edu/.

U.S. Department of Labor, Bureau of Labor Statistics (1938) "Retail Prices of Food 1923-36," Bulletin, no. 635. Washington D.C.: Bureau of Labor Statistics.

(1941) "Changes in Cost of Living in Large Cities in the United States, 1914-41,” Bulletin, no. 699, Washington D.C.: Bureau of Labor Statistics.

(1941) Handbook of Labor Statistics Bulletin No. 694, vols. I and II. Washington D.C.: Bureau of Labor Statistics.

U.S. Department of Commerce, Bureau of the Census (1975) Historical Statistics of the United States, Parts 1 and 2 (Bicentennial Edition), Washington D.C.: Bureau of the Census.

Washington D.C.: Government Printing Office.

(1939) Statistical Abstract of the United States 1938, 
U.S. Department of Commerce, Bureau of Economic Analysis (1998), "GDP AND OTHER MAJOR NIPA SERIES, 1929-97” Survey of Current Business, Aug 98, Vol. 78, Issue 8.

Yamamoto, Yuzou (2000), Nihon Shokuminchi Keizai Shi Kenkyu (Studies on the Economic History of Japanese Colonies), Nagoya: Nagoya University Publishing House.

Yuan Tangjun (2005) "Cyugoku no Keizai Hatten no Shoki Jokyo: 1930 Nendai Niokeru Jissitsu Shohi Suijun no Kokusai Hikaku (The Initial Condition of China's Economic Growth: An International Comparison of Per Capita Real Consumption Level in the 1930s)," Chapter 1 in T. Yuan, Chugoku no Keizai Hatten to Bumonkan Shigen Haibun (China's Economic Growth and the Resource Reallocation among Sectors), Ph.D. Dissertation, Graduate School of Economics, Hitotsubashi University.

Wang, Qingyi (1988) Zhongguo Nenyuan (Chinese Energy). Beijing: China Metallic Industry Press.

Ward, Marianne, and John Devereux (2003) "Measuring British Decline: Direct Versus Long-Span Income Measures.” Journal of Economic History. Vol. 63, no. 3, 826-51.

Ward, Marianne, and John Devereux (2005) "International Comparisons of Incomes, Labor Productivity and Capital Stocks for Developed Economies: 1870-1950," paper presented at UC Davis workshop, Estimating Production and Income Across Nations and over Time, May 31-June 1, 2005, Davis, CA: UC Davis, Institute of Governmental Affairs.

Watanabe, Tsunehiko, and Komiya, Ryutaro (1958) "Findings from Price Comparisons Principally Japan vs. the United States" Zeitschrift des Instituts für Weltwirtschaft an der Universität Kiel, vol. 81, no. 1, pp. 81-96.

Zhao, Xiaomei (1939) Sichuan Jingji Cankao Ziliao (Reference Materials on Sichuan Economy), Shanghai:

Institute of Chinese National Economy. 
Table 1. Consumption Price Levels of China Relative to Japan (1934-36 Japan =1)

\begin{tabular}{|c|ccc|}
\hline & $\begin{array}{c}\text { Chinese } \\
\text { expenditure } \\
\text { weight }\end{array}$ & $\begin{array}{c}\text { Japanese } \\
\text { expenditure } \\
\text { weight }\end{array}$ & $\begin{array}{c}\text { Fisher } \\
\text { average }\end{array}$ \\
\hline Total & 0.65 & 0.83 & 0.73 \\
\hline Food & 0.66 & 0.79 & 0.72 \\
Lighting and heat & 0.58 & 1.12 & 0.80 \\
Clothing and bedding & 0.63 & 1.16 & 0.86 \\
Housing expenses & 0.57 & 0.49 & 0.53 \\
Miscellaneous & 0.75 & 0.84 & 0.79 \\
\hline
\end{tabular}

Source: See text.

Table 2. Consumption Price Levels of Japan Relative to the U.S (1934-36 U.S =1)

\begin{tabular}{|c|ccc|}
\hline & $\begin{array}{c}\text { Japanese } \\
\text { expenditure } \\
\text { weight }\end{array}$ & $\begin{array}{c}\text { U.S. } \\
\text { expenditure } \\
\text { weight }\end{array}$ & $\begin{array}{c}\text { Fisher } \\
\text { average }\end{array}$ \\
\hline Total & 0.34 & 0.58 & 0.45 \\
\hline Food & 0.37 & 0.62 & 0.48 \\
Lighting and heat & 1.06 & 0.89 & 0.97 \\
Clothing and bedding & 0.25 & 0.49 & 0.35 \\
Housing expenses & 0.59 & 0.67 & 0.63 \\
Miscellaneous & 0.28 & 0.48 & 0.36 \\
\hline
\end{tabular}

Source: See text.

Table 3. Consumption Price Levels of China Relative to the U.S (1934-36 U.S =1)

\begin{tabular}{|c|ccc|}
\hline & $\begin{array}{c}\text { Chinese } \\
\text { expenditure } \\
\text { weight }\end{array}$ & $\begin{array}{c}\text { U.S. } \\
\text { expenditure } \\
\text { weight }\end{array}$ & $\begin{array}{c}\text { Fisher } \\
\text { average }\end{array}$ \\
\hline Total & 0.26 & 0.38 & 0.32 \\
\hline Food & 0.27 & 0.35 & 0.31 \\
Lighting and heat & 0.70 & 0.92 & 0.80 \\
Clothing and bedding & 0.24 & 0.28 & 0.26 \\
Housing expenses & 0.15 & 0.24 & 0.19 \\
Miscellaneous & 0.21 & 0.47 & 0.32 \\
\hline
\end{tabular}

Source: See text. 
Table 4. Consumption Price Levels of East Asian Countries Relative to the U.S. (Fisher Average)

1934-36 U.S. $=1$

\begin{tabular}{|c|cccc|}
\hline & China & Taiwan & Korea & Japan \\
\hline Total & 0.32 & 0.39 & 0.43 & 0.45 \\
\hline Food & 0.31 & 0.42 & 0.45 & 0.48 \\
Lighting and heat & 0.80 & 0.77 & 0.80 & 0.97 \\
Clothing and bedding & 0.26 & 0.33 & 0.33 & 0.35 \\
Housing expenses & 0.19 & 0.46 & 0.55 & 0.62 \\
Miscellaneous & 0.32 & 0.30 & 0.26 & 0.36 \\
\hline Tradable* & 0.77 & 0.88 & 0.93 & 0.55 \\
Non-tradable* & 0.68 & 0.78 & 0.71 & 0.39 \\
\hline
\end{tabular}

*Relative price levels for tradable and non-tradable for Japan are calculated relative to the U.S. The rest three economies are computed relative to Japan.

Notes:

1. Tradable goods for Korea and Taiwan can be found in Fukao, Ma and Yuan (2006).

2. Tradable goods for China: food, clothing and bedding, firewood, coal, matches, lamp oil, wooden boards, wash basins, hygiene products, soap, toothbrushes, medical alcohol.

3. Tradable goods for Japan are items marked with "l" in Appendix Table II.

4. For the Japan-China comparison, the weights used for tradables are 63 percent for Japan and 89 percent for China. For the Japan-U.S. comparison, the weights used for tradables are 47 percent for Japan and 42 percent for the U.S. 
Table 5. Relative Price Levels for Private Investment for Japan and the U.S in 1935

\begin{tabular}{|c|c|c|c|c|c|c|}
\hline & & & & se price lev & (U.S. $=1)$ & \\
\hline & Japan & U.S. & Japan/U.S. & $\begin{array}{c}\text { Japanese } \\
\text { weight }\end{array}$ & $\begin{array}{c}\text { U.S. } \\
\text { weight }\end{array}$ & $\begin{array}{l}\text { Fisher } \\
\text { average }\end{array}$ \\
\hline Equipment (Machinery and equipment) & 0.5 & 0.5 & 0.88 & 0.88 & 0.88 & 0.88 \\
\hline Construction & & & & 0.22 & 0.51 & 0.34 \\
\hline Cement & 0.0625 & 0.075 & 0.68 & & & \\
\hline Pig iron & 0.0625 & 0.075 & 0.78 & & & \\
\hline Nails & 0.0625 & 0.075 & 0.72 & & & \\
\hline Tin plate & 0.0625 & 0.075 & 0.87 & & & \\
\hline Wages & 0.25 & 0.2 & 0.13 & & & \\
\hline Total & 1.0 & 1.0 & & 0.35 & 0.69 & 0.50 \\
\hline
\end{tabular}

Sources:

1. The Japan/U.S. relative price for equipment (metals and machinery) is from Pilat (1994), Table 2.5, p. 27. construction wages are from Appendix Table II. Relative prices for the rest are from wholesale price statistics of both U.S. and Japan.

2. The weights for Japanese equipment and construction investment are based on Emi (1971), p. 10; for the U.S. the weights are based on Historical Statistics, Part I, p. 283 for 1947. The shares of raw materials and labor for construction investment for U.S. are from Historical Statistics, Part I, p. 282; for Japan, they are from Fukao, Ma, and Yuan (2006).

Table 6. Relative Price Levels for Government Expenditure for Japan and the U.S. in $\mathbf{1 9 3 5}$

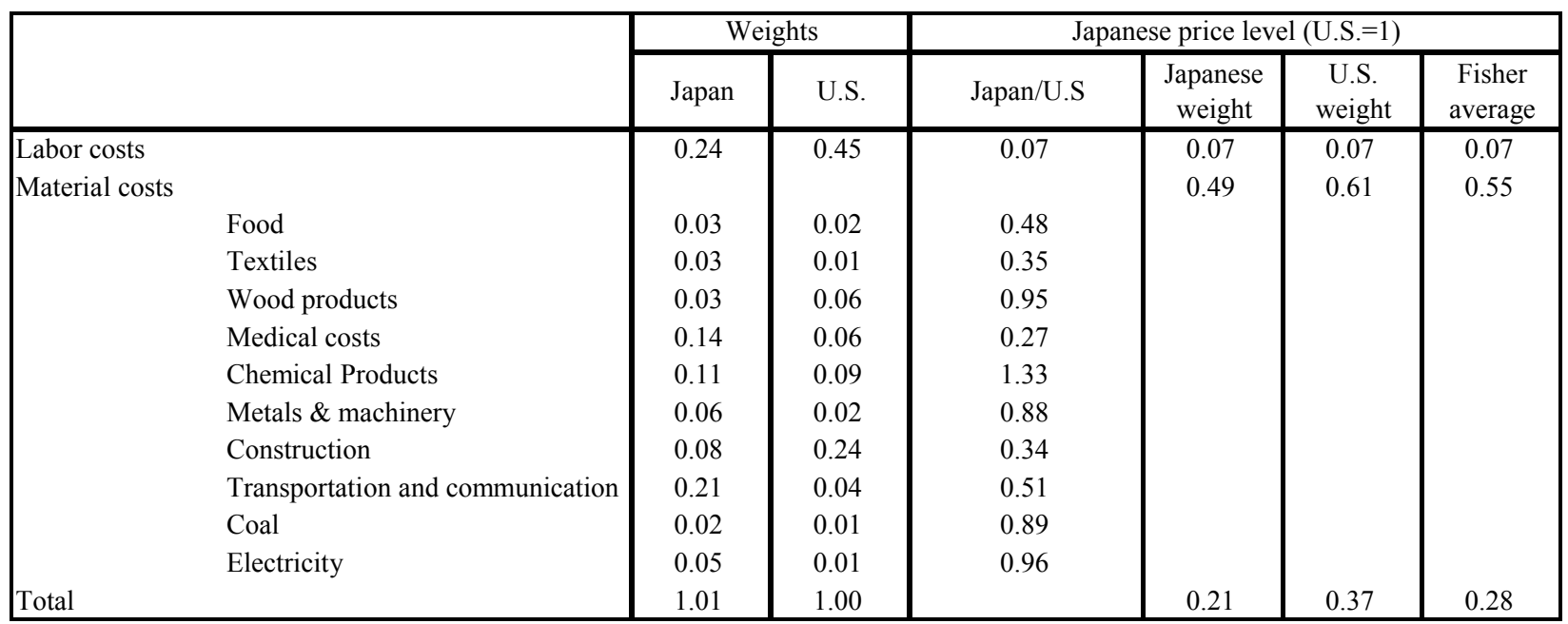

Sources:

1. Labor costs for Japan are based on the salaries of government employees taken from Emi and Shionoya (1966), which includes the additional bonus (see pp. 222-3 and footnote on p.222 for the bonus part). Labor costs for U.S. are from Historical Statistics, Part II, pp. 1100-1. Data on chemical products, metals \& machinery, transportation and communication are from Pilat (1994), p. 24. The remaining figures are from Appendix Table II.

2. The weight for labor and material costs for Japan is based on Emi and Shionoya (1966), pp.31-2; the equivalent weight for the U.S. is based on Historical Statistics, pp. 282-3. (The share of material costs is assumed to be equal to the share of total intermediate inputs in government purchases, while value added is assumed to be equal to labor costs. The U.S. shares used are for the 1950s and 60s). The weights for materials for Japan are based on Fukao, Ma, and Yuan (2006), Table 5. The weights for materials for the U.S. are based on Historical Statistics, pp. 282-3. 
Table 7. East Asian Price Levels Relative to the U.S. (1934-36)

\begin{tabular}{|c|c|c|c|c|c|c|c|}
\hline & \multicolumn{4}{|c|}{ Expenditure weight } & \multicolumn{3}{|c|}{$\begin{array}{c}\text { Relative price level (Fisher } \\
\text { average, U.S. }=1 \text { ) }\end{array}$} \\
\hline & Taiwan & Korea & Japan & U.S. & Taiwan & Korea & Japan \\
\hline Consumption & 0.73 & 0.84 & 0.70 & 0.77 & 0.39 & 0.43 & 0.45 \\
\hline Private investment & 0.20 & 0.11 & 0.18 & 0.08 & 0.47 & 0.49 & 0.50 \\
\hline Government expenditure & 0.07 & 0.05 & 0.12 & 0.15 & 0.24 & 0.25 & 0.28 \\
\hline GDP & 1.00 & 1.00 & 1.00 & 1.00 & 0.38 & 0.41 & 0.43 \\
\hline
\end{tabular}

Source Note: Price levels and weights for Korea and Taiwan are based on Fukao, Ma, and Yuan (2006). US weights are based on U.S. Department of Commerce (1998), “GDP AND OTHER MAJOR NIPA SERIES, 1929-97” Survey of Current Business, Aug 1998, p.147.

Table 8. 1934-36 East Asian Per Capita GDPs in 1934-36 U.S. Dollars and Relative to the U.S

\begin{tabular}{|c|c|c|c|c|c|}
\hline & U.S. & Japan & Taiwan & Korea & China \\
\hline \multirow{2}{*}{ 1. Exchange rate converted estimate } & 574.7 & 77.1 & 49.2 & 29.1 & 20.1 \\
& $100 \%$ & $13.4 \%$ & $8.6 \%$ & $5.1 \%$ & $3.5 \%$ \\
\hline 2. Relative GDP price levels & 1 & 0.43 & 0.38 & 0.41 & 0.32 \\
\hline 3. PPP adjusted estimate $=1 \div 2$ & 574.7 & 180.8 & 129.6 & 70.9 & 63.6 \\
& $100 \%$ & $31.5 \%$ & $22.6 \%$ & $12.3 \%$ & $11.1 \%$ \\
\hline
\end{tabular}

Sources:

1. GDP for China from Liu and Yeh, p. 68, Table 10; for Japan from Ohkawa and Shinohara (1979), for Taiwan and Korea from Mizoguchi and Umemura (1988); for the U.S. from the Historical Statistics of the U.S. (the Bicentennial Edition, 1975).

2. 1934-36 exchanges rates: 1 U.S. dollar = 3.43 Japanese yen=3.01 Chinese yuan from Hsiao, p. 192 . 
Table 9. Comparison of Relative Price Levels in pre- and Post-War Periods (U.S. $=$ 100) (Numbers in parentheses are PPP adjusted per capita incomes relative to the U.S)

\begin{tabular}{|c|c|c|c|c|c|}
\hline & Japan & Korea* & Taiwan & China & Sources \\
\hline \multirow[t]{2}{*}{$1934-36$} & $35(39)$ & $23(22)$ & $40(22)$ & $35(10)$ & Maddison back-projection \\
\hline & $43(32)$ & $41(13)$ & $38(23)$ & $32(11)$ & This study \\
\hline \multicolumn{6}{|c|}{ Expenditure based PPP } \\
\hline 1952 & $52(18)$ & & & & Watanabe and Komiya 1958 \\
\hline 1967 & $63(48)$ & & & & Kravis et al, 1975, p.238-9 \\
\hline 1970 & $68(59)$ & $47(12)$ & & & Kravis et al, 1982, p.13and 21 \\
\hline 1973 & $95(64)$ & $43(15)$ & & & Kravis et al, 1982, p. 13 and 21 \\
\hline 1975 & $90(68)$ & $39(21)$ & & & Kravis et al, 1982, p.13 and 21 \\
\hline 1985 & $93(72)$ & $53(24)$ & $57(34)$ & & Yotopulos and Lin, p.14. \\
\hline 1986 & & & & $23(8)$ & Maddison 1998, p.153-4 \\
\hline \multicolumn{6}{|c|}{ Production based PPP } \\
\hline 1939 & $61(27)$ & & & & Pilat, 1994, pp. 24, \\
\hline 1965 & $55(46)$ & $38(8)$ & $33(18)$ & & Maddison 1970, p. 295 \\
\hline 1975 & $106(53)$ & $66(18)$ & & & Pilat 1994, p.118,121 \\
\hline 1985 & $101(65)$ & $66(31)$ & & & Pilat 1994, p.152,154 \\
\hline
\end{tabular}

*South Korea for the post-WWII period

Source Notes:

1952 is from Watanabe and Komiya 1958. The study did not include, for example, expenditure on energy and housing, the relatively high-priced items in Japan. It did not calculate relative per capita GDP for 1952. We recalculate it with the exchange rate at 1 U.S. dollar $=360$ yen and the $52 \%$ relative price levels. The per capita GDP estimates for Japan and the U.S. in 1938 and 1952 current prices are from Ohkawa and Shinohara (1979, p.283) and Historical Statistics of the United States (1975, p. F10-30).

Maddison's PPP converter for China-US in 1986 is based on study by Ren Rouen. 
Figure 1. Comparison of Our Current Price PPP Per Capita GDP with Maddison's Back-Projected Estimate (in 1990 U.S. Dollars)

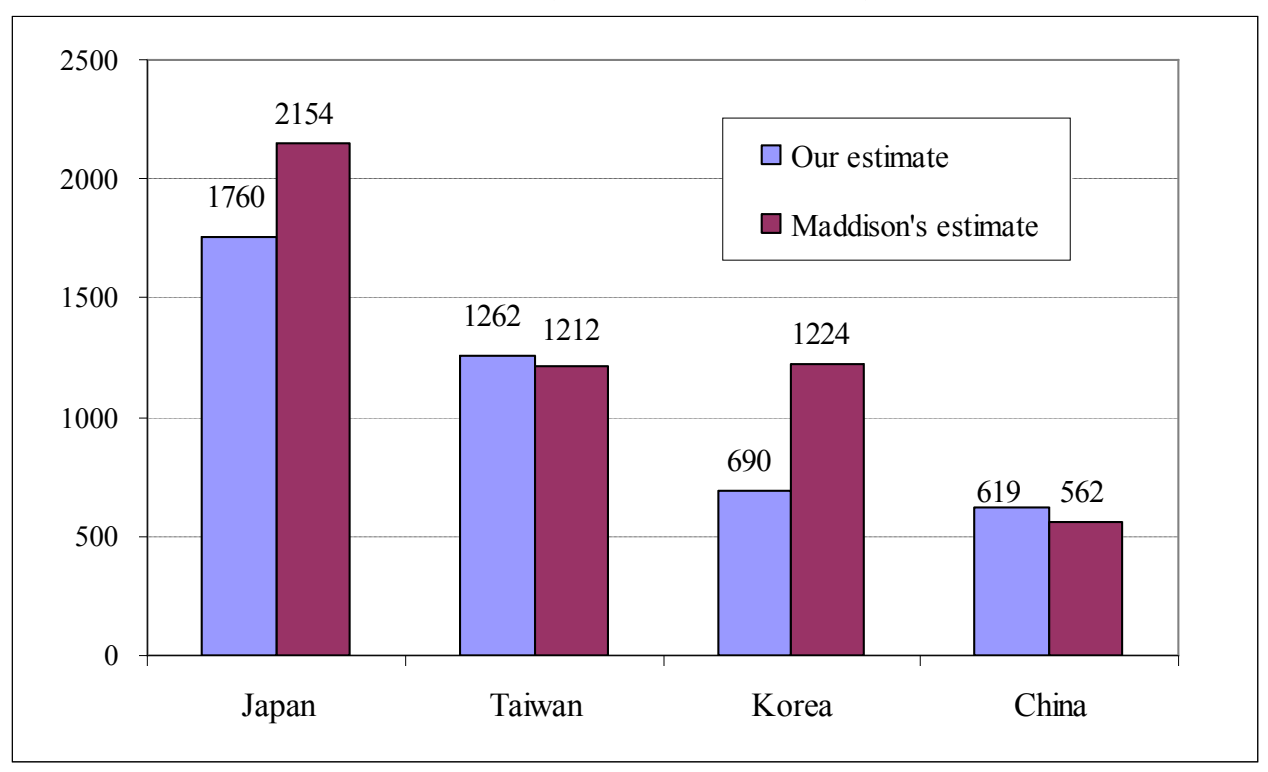


Appendix Table I. Chinese Price Level Relative to Japan (1934-36: Japan=1)

\begin{tabular}{|c|c|c|c|c|c|c|c|c|c|c|c|c|c|}
\hline & & & nese we & & & nese we & ight & & & & Price & & \\
\hline & Items & I & II & III & I & II & III & Unit & Japan & China & $\begin{array}{c}\text { China/Japan } \\
\text { in PPP }\end{array}$ & PPP/ER & $\begin{array}{l}\text { Chinese } \\
\text { weight }\end{array}$ \\
\hline Total & Exchange rate & & & & & & & & Yen & Yuan & Yuan/Yen & $\begin{array}{l}E R=0.88 \\
\text { Yuan/yen }\end{array}$ & 0.65 \\
\hline Food & & 68.7 & & & 40.9 & & & & & & & & 0.66 \\
\hline Grain & & & 68.5 & 100.0 & & 35.3 & 100.0 & & & & & & 0.68 \\
\hline & Rice & & & 69.9 & & & 93.3 & $1 \mathrm{~kg}$ & 0.24 & 0.14 & 0.59 & 0.67 & 1.04 \\
\hline & Wheat & & & 30.1 & & & 6.7 & $1 \mathrm{~kg}$ & 0.21 & 0.13 & 0.63 & 0.72 & 0.42 \\
\hline $\begin{array}{l}\text { Vegetables } \\
\text { and fruits }\end{array}$ & & & 8.8 & 100.0 & & 8.9 & 100.0 & & & & & & 0.70 \\
\hline & Soybeans & & & 1.7 & & & 13.9 & $1 \mathrm{~kg}$ & 0.23 & 0.11 & 0.45 & 0.52 & 0.03 \\
\hline & Other beans & & & 7.3 & & & 9.8 & $1 \mathrm{~kg}$ & 0.19 & 0.06 & 0.35 & 0.40 & 0.18 \\
\hline & Potatoes & & & 5.9 & & & 2.9 & $1 \mathrm{~kg}$ & 0.07 & 0.03 & 0.38 & 0.43 & 0.14 \\
\hline & Cabbages & & & 63.0 & & & 43.7 & $1 \mathrm{~kg}$ & 0.08 & 0.06 & 0.66 & 0.75 & 0.84 \\
\hline & Green onion & & & 2.3 & & & 9.9 & $1 \mathrm{~kg}$ & 0.08 & 0.03 & 0.39 & 0.44 & 0.05 \\
\hline & Drying vegetables & & & 9.0 & & & 9.9 & $\begin{array}{l}10 \text { monme }(37.5 \mathrm{~g}) \\
100 \text { monme }(375\end{array}$ & 0.18 & 0.12 & 0.66 & 0.75 & 0.12 \\
\hline & Apples & & & 0.1 & & & 2.5 & $\begin{array}{l}\text { g) } \\
100 \text { monme }(375\end{array}$ & 0.15 & 0.30 & 1.99 & 2.26 & 0.00 \\
\hline & Oranges & & & 0.3 & & & 2.5 & g) & 0.08 & 0.14 & 1.78 & 2.03 & 0.00 \\
\hline & Bananas & & & 0.1 & & & 2.5 & $\begin{array}{l}1 \mathrm{~kg} \\
100 \text { monme }(375\end{array}$ & 0.20 & 0.40 & 2.03 & 2.31 & 0.00 \\
\hline & Other fruits & & & 10.1 & & & 2.5 & g) & 0.10 & 0.14 & 1.37 & 1.56 & 0.06 \\
\hline Ingredients & & & 7.4 & 100.0 & & 8.5 & 100.0 & & & & & & 0.98 \\
\hline & Soysauce & & & 18.0 & & & 27.0 & 1 litter & 0.27 & 0.47 & 1.74 & 1.98 & 0.09 \\
\hline & Miso & & & 8.0 & & & 17.7 & $1 \mathrm{~kg}$ & 0.22 & 0.18 & 0.82 & 0.93 & 0.09 \\
\hline & Sugar & & & 11.6 & & & 11.5 & $1 \mathrm{~kg}$ & 0.40 & 0.48 & 1.21 & 1.38 & 0.08 \\
\hline & Salt & & & 8.3 & & & 3.5 & $1 \mathrm{~kg}$ & 0.07 & 0.22 & 3.00 & 3.41 & 0.02 \\
\hline & Oil & & & 54.2 & & & 40.4 & 1 litter & 1.03 & 0.67 & 0.65 & 0.74 & 0.73 \\
\hline Meat and & & & & & & & & & & & & & \\
\hline Fish & & & 5.9 & 100.0 & & 13.5 & 100.0 & & & & & & 0.36 \\
\hline & Pork & & & 38.1 & & & 5.3 & $100 \mathrm{~g}$ & 0.14 & 0.04 & 0.32 & 0.36 & 1.06 \\
\hline & Beef & & & 27.0 & & & 12.8 & $100 \mathrm{~g}$ & 0.16 & 0.04 & 0.23 & 0.26 & 1.05 \\
\hline & Chicken & & & 2.5 & & & 2.0 & $100 \mathrm{~g}$ & 0.21 & 0.07 & 0.34 & 0.39 & 0.06 \\
\hline & Fresh fish & & & 14.9 & & & 20.5 & $1 \mathrm{~kg}$ & 0.71 & 0.38 & 0.54 & 0.61 & 0.24 \\
\hline & Salty fish & & & 3.8 & & & 20.5 & $1 \mathrm{~kg}$ & 1.15 & 1.85 & 1.62 & 1.84 & 0.02 \\
\hline & Other seafood & & & 6.3 & & & 20.5 & $1 \mathrm{~kg}$ & 0.75 & 0.20 & 0.26 & 0.30 & 0.21 \\
\hline & Eggs & & & 5.9 & & & 14.3 & $1 \mathrm{~kg}$ & 0.62 & 0.37 & 0.59 & 0.67 & 0.09 \\
\hline & Milk & & & 1.4 & & & 4.3 & 1 bottle & 0.37 & 0.62 & 1.67 & 1.90 & 0.01 \\
\hline Others & & & 1.0 & 100.0 & & 23.8 & 100.0 & & & & & & 0.77 \\
\hline & Sweets & & & 11.7 & & & 25.0 & $1 \mathrm{~kg}$ & 0.16 & 0.12 & 0.76 & 0.86 & 0.14 \\
\hline & Preserved vegetables (Pickles) & & & 21.6 & & & 25.0 & $1 \mathrm{~kg}$ & 0.16 & 0.12 & 0.76 & 0.86 & 0.25 \\
\hline & Tofu & & & 25.1 & & & 25.0 & $\begin{array}{l}1 \text { cake } \\
100 \text { monme ( } 375\end{array}$ & 0.07 & 0.03 & 0.45 & 0.52 & 0.49 \\
\hline Drinks and & Other processed food & & & 41.6 & & & 25.0 & g) & 0.07 & 0.06 & 0.86 & 0.97 & 0.43 \\
\hline $\begin{array}{l}\text { Drinks and } \\
\text { Tobacco }\end{array}$ & & & 8.4 & 100.0 & & 9.9 & 100.0 & & & & & 0.00 & 0.59 \\
\hline & Tobacco & & & 51.4 & & & 39.1 & 1 package & 0.15 & 0.16 & 1.06 & 1.20 & 0.43 \\
\hline & Alcohol & & & 20.9 & & & 48.7 & 1 litter & 0.85 & 0.15 & 0.18 & 0.21 & 1.02 \\
\hline & Tea & & & 27.7 & & & 12.1 & $100 \mathrm{~g}$ & 0.19 & 0.19 & 1.03 & 1.17 & 0.24 \\
\hline Lighting and Heating & & 8.3 & & & 4.8 & & & & & & & & 0.58 \\
\hline Electricity & & & 0.3 & 100.0 & & 47.6 & 100.0 & $1 \mathrm{kwh}$ & 0.14 & 0.16 & 1.16 & 1.31 & 1.31 \\
\hline Fuel & & & 97.0 & 100.0 & & 48.9 & 100.0 & & & & & & 0.57 \\
\hline & Coal & & & 6.0 & & & 11.8 & $10 \mathrm{~kg}$ & 0.27 & 0.11 & 0.41 & 0.46 & 0.13 \\
\hline & Firewood & & & 77.0 & & & 38.8 & $10 \mathrm{~kg}$ & 0.26 & 0.12 & 0.45 & 0.52 & 1.49 \\
\hline & Charcoal & & & 1.7 & & & 40.8 & $10 \mathrm{~kg}$ & 0.81 & 1.00 & 1.24 & 1.41 & 0.01 \\
\hline & Lamp oil & & & 15.3 & & & 8.6 & $\begin{array}{l}1 \mathrm{~kg} \\
1 \text { packet }\end{array}$ & 0.26 & 0.28 & 1.09 & 1.24 & 0.12 \\
\hline Others & Matches & & 2.7 & 100.0 & & 3.5 & 100.0 & (10boxes) & 0.06 & 0.05 & 0.82 & 0.94 & 0.94 \\
\hline Clothing and Beddin & & 8.5 & & & 10.7 & & & & & & & & 0.63 \\
\hline Clothing & & & 80.3 & 100.0 & & 72.8 & 100.0 & & & & & & 0.63 \\
\hline & Cotton Weaver's wage (Female) b) & & & 79.4 & & & 49.8 & daily & 0.65 & 0.32 & 0.49 & 0.56 & 1.42 \\
\hline & Sweatshirt & & & 11.3 & & & 49.7 & 1 piece & 0.88 & 1.48 & 1.68 & 1.91 & 0.06 \\
\hline & Cotton & & & 9.2 & & & 0.5 & $1 \mathrm{~kg}$ & 0.98 & 0.71 & 0.72 & 0.82 & 0.11 \\
\hline Personal & & & & & & & & & & & & & \\
\hline items & & & 19.7 & 100.0 & & 27.2 & 100.0 & & & & & & 0.66 \\
\hline & Sports shoes & & & 25.0 & & & 34.9 & 1 pair & 0.70 & 1.07 & 1.53 & 1.74 & 0.14 \\
\hline & Shoe Maker's wage $b$ ) & & & 25.0 & & & 34.9 & daily & 1.77 & 0.73 & 0.41 & 0.47 & 0.53 \\
\hline & Umbrella & & & 50.0 & & & 30.3 & 1 piece & 0.89 & 0.47 & 0.53 & 0.60 & 0.84 \\
\hline Housing & & 5.3 & & & 10.7 & & & & & & & & 0.57 \\
\hline Rent & & & 61.6 & 100.0 & & 97.3 & 100.0 & & & & & & 0.46 \\
\hline & & & & & & & & 1 room $(7.43 \mathrm{sq}$. & & & & & \\
\hline & Monthly housing rent $c$ ) & & & 33.4 & & & 33.4 & m.) & 5.09 & 1.72 & 0.34 & 0.38 & 0.87 \\
\hline & Carpenter's wage $b$ ) & & & 33.3 & & & 33.3 & daily & 1.97 & 0.96 & 0.49 & 0.55 & 0.60 \\
\hline & Brick $d$ ) & & & 33.3 & & & 33.3 & 1000pieces & 22.18 & 9.11 & 0.41 & 0.47 & 0.71 \\
\hline Furniture & & & 38.4 & 100.0 & & 2.7 & 100.0 & & & & & & 0.97 \\
\hline & Wooden board & & & 33.4 & & & 33.4 & 3.3 sq. m. & 1.98 & 1.68 & 0.85 & 0.96 & 0.35 \\
\hline & Sawer's wage $b$ ) & & & 33.3 & & & 33.3 & daily & 1.55 & 0.91 & 0.59 & 0.67 & 0.50 \\
\hline & Wash basin & & & 33.3 & & & 33.3 & 1 piece & 0.31 & 0.49 & 1.56 & 1.77 & 0.19 \\
\hline Miscellaneous Expen & nses & 9.2 & & & 32.9 & & & & & & & & 0.75 \\
\hline Trans. & & & 4.9 & 100.0 & & 6.2 & 100.0 & & & & & & 0.40 \\
\hline & $\begin{array}{l}\text { Rickshaw pullers' wage } b \text { ) } \\
\text { Average railroad fares per passenger- }\end{array}$ & & & 50.0 & & & 50.0 & daily & 2.67 & 0.54 & 0.20 & 0.23 & 2.18 \\
\hline & 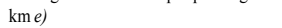 & & & 50.0 & & & 50.0 & & 0.01 & 0.02 & 1.30 & 1.47 & 0.34 \\
\hline Education & & & 1.5 & 100.0 & & 5.8 & 100.0 & & & & & & 0.37 \\
\hline & Teachers' wage $b$ ) & & & 50.0 & & & 50.0 & monthly & 65.91 & 12.50 & 0.19 & 0.22 & 2.32 \\
\hline & Pencil & & & 50.0 & & & 50.0 & & 0.03 & 0.04 & 1.23 & 1.40 & 0.36 \\
\hline Hygience & & & 9.9 & 100.0 & & 10.4 & 100.0 & & & & & & 1.17 \\
\hline & Soap & & & 25.0 & & & 25.0 & 1 piece & 0.10 & 0.20 & 2.00 & 2.27 & 0.11 \\
\hline & Toothbrush (Tokyo) & & & 25.0 & & & 25.0 & 1 piece & 0.15 & 0.21 & 1.40 & 1.59 & 0.16 \\
\hline & Haircut $f f$ & & & 50.0 & & & 50.0 & once & 0.40 & 0.30 & 0.75 & 0.85 & 0.59 \\
\hline $\begin{array}{l}\text { Medicine } \\
\text { Entertainme }\end{array}$ & Liushenwan (Chinese medicine) \&) & & 5.8 & 100.0 & & 12.8 & 100.0 & 1 tablet & 0.05 & 0.01 & 0.26 & 0.30 & 0.30 \\
\hline $\mathrm{nt}$ & Movie $h$ ) & & 19.2 & 100.0 & & 21.3 & 100.0 & once & 0.30 & 0.20 & 0.67 & 0.76 & 0.76 \\
\hline Other & Newspapers l) & & 58.7 & 100.0 & & 43.5 & 100.0 & 1 set & 0.05 & 0.04 & 0.80 & 0.91 & 0.91 \\
\hline
\end{tabular}


Source Notes:

* The number of cities in our sample is ordered as follows: 1.Shanghai, 2.Shijiazhuang, 3.Chongqing, 4.Guangzhou, 5.Zhengzhou, 6.Nanjing, 7. Lanzhou, 8.Hangzhou, 9.Tianjin, 10.Wuhan, 11.Beijing.

1. Price data are mostly based on "Archival Materials for Studies of Industrial and Agricultural Commodity Prices." For some cities where prices are missing for some items in our sample, we use the average prices of their neighboring cities as follows: for Chongqing, we use the average prices of Nanchong、 Jianyang、 Lizhuang; For Wuhan, we use the average of Shashi,Shuanggou, Shadaoguan, Ziqiu; for Guangzhou, we use Shantou; for Beijing, we use Zhangjiakou, For Nanjing, we use the average of Wuxi, Erjiazheng,Suqian,Xuzhou, For Lanzhou, we use the average of Xining and Huangyuan; for Shijiazhuang, we use the average of Baoding, Dingxian, Tangshan; for Zhengzhou, we use the average of Zhengping and Linbao; for Hangzhou, we use the average of Pinghu and Yiwu. Prices for Beijing are the average of 1934-35 from China Economic Statistics Annals.

2. For weights, see the text. For Housing and Miscellaneous, we use simple average for the lower level weights.

a) Average of Chongqing and Wuxi. Chongqi from Sichaun Economic Reference Materials for 1935, Wuxi is the average of 1934-35 from China Economic Statistics Annals. Japan is for Tokyo only.

b) Teachers' wages in China are estimated from Hao Jinhua (2005) "Income of Private School Teachers in 1920-30s" in Fujian Tribune (Monthly wages converged from annual salaries). Japan is from Statistical Annals of Japanese Empire. Ricksaw Pullers' daily wages in China from Shanghai Local Gazette Office (at http://www.shtong.gov.cn/). Other Chinese wages from China Economic Statistics Annals with daily wages converted into monthly income by multiplying 25 days. Japanese wages from Ohkawa et al, LTES. Vol. 8. Price.

c) Average of Tianjin and Beijing. Tianjing from Nankai Economic Indices, Beijing from China Economic Statistics Annals. Japan is for Tokyo.

d) Wholesale prices.

e) The railroad fares per passenger-km is the average of Jing-han line (1936), Bei-ning line (1935) and Jingpu line (1935) reported in World Rail Statistics. Japan is from Rail Statistics.

f) Chinese price from Wuhan Local Gazette Office (Homepage : http://www.whfz.gov.cn/) . Japanese price is for Tokyo.

g) Japan is from Asahi News for 1934-36.

h) Dagong Daily for 1934-36.

i) Price of gasoline is from 'Newspaper Article in digital version' at Kobe University at http://www.lib.kobeu.ac.jp/sinbun/e-index.html, and the original source is Chugai shogyo simpo 1935.9.26. 
Appendix Table II. Japanese Price Level Relative to U.S. (1934-36: US=1)

\begin{tabular}{|c|c|c|c|c|c|c|c|c|c|c|c|c|c|c|c|c|c|c|}
\hline & & & nese $w$ & & & S. weig & & U.S. units & Japanese units & & & rices & & Japa & nese price & level & & \\
\hline Item & & I & II & III & I & II & III & & & U.S. & Japan & $\begin{array}{l}\text { Japan/U. } \\
\text { S. in PPP }\end{array}$ & PPP/ER & $\begin{array}{c}\text { Japanese } \\
\text { weight }\end{array}$ & $\begin{array}{c}\text { U.S. } \\
\text { weight }\end{array}$ & $\begin{array}{c}\text { Fisher } \\
\text { average }\end{array}$ & $\begin{array}{l}\text { the U.S. } \\
\text { ICPSR data }\end{array}$ & $\mathrm{s}$ \\
\hline Total & Exchange rate & & & & & & & & & dollars & yen & & $\begin{array}{l}E R=3.43 \\
Y e n / U S \$\end{array}$ & 0.34 & 0.60 & 0.45 & & \\
\hline Food & & 41.3 & & & 33.2 & & & & & & & & & 0.37 & 0.62 & 0.48 & & \\
\hline Grain and bread & & & 39.7 & 100.0 & & 12.0 & 100.0 & Unit & Unit & & & & & 0.39 & 0.60 & 0.48 & & 1 \\
\hline & Rice & & & 92.9 & & & 3.1 & $1 \mathrm{lb}$ & $1 \mathrm{~kg}$ & 0.08 & 0.24 & 1.30 & 0.38 & & & & & \\
\hline & Wheat flour & & & 5.8 & & & 16.7 & $1 \mathrm{lb}$ & $1 \mathrm{~kg}$ & 0.05 & 0.23 & 2.11 & 0.62 & & & & & \\
\hline & $\operatorname{Bread} l, a$ & & & 1.2 & & & 80.6 & $1 \mathrm{lb}$ & $1 \mathrm{lb}$ & 0.08 & 0.17 & 2.05 & 0.60 & & & & & \\
\hline Meat & & & 2.7 & 100.0 & & 19.8 & 100.0 & & & & & & & 0.91 & 0.94 & 0.93 & & 1 \\
\hline & Beef & & & 63.9 & & & 51.7 & $1 \mathrm{lb}$ & $1 \mathrm{~kg}$ & 0.14 & 1.28 & 4.04 & 1.18 & & & & & \\
\hline & Pork & & & 26.8 & & & 34.1 & $1 \mathrm{lb}$ & $1 \mathrm{~kg}$ & 0.32 & 1.40 & 2.01 & 0.59 & & & & & \\
\hline & Chicken & & & 9.4 & & & 14.2 & $1 \mathrm{lb}$ & $1 \mathrm{~kg}$ & 0.29 & 2.08 & 3.21 & 0.94 & & & & & \\
\hline Fish & & & 8.3 & 100.0 & & 1.3 & 100.0 & & & & & & & 0.26 & 0.25 & 0.26 & & 0 \\
\hline & $1, a$ & & & 54.4 & & & 52.3 & $1 \mathrm{lb}$ & 100 monme & 0.24 & 0.15 & 0.77 & 0.22 & & & & 43 & \\
\hline & Mackerel $a$ & & & 43.0 & & & 16.5 & $1 \mathrm{lb}$ & 100 monme & 0.12 & 0.11 & 1.19 & 0.35 & & & & 24 & \\
\hline & Salmon $l, a$ & & & 2.5 & & & 31.1 & $1 \mathrm{lb}$ & 100 monme & 0.24 & 0.17 & 0.85 & 0.25 & & & & 24 & \\
\hline Milk and Eggs & & & 2.5 & 100.0 & & 18.9 & 100.0 & & & & & & & 0.36 & 0.86 & 0.56 & & 0 \\
\hline & Milk & & & 23.0 & & & 77.6 & 1 qt. & $1 \mathrm{go}(180 \mathrm{cc})$ & 0.12 & 0.08 & 3.52 & 1.02 & & & & & \\
\hline & Eggs & & & 77.0 & & & 22.4 & 1 doz & $1 \mathrm{~kg}$ & 0.36 & 0.62 & 1.03 & 0.30 & & & & & \\
\hline Ingredients & & & 8.5 & 100.0 & & 3.0 & 100.0 & & & & & & & 0.73 & 0.81 & 0.77 & & 1 \\
\hline & Salt $a$ & & & 10.3 & & & 10.3 & $1 \mathrm{lb}$ & $1 \mathrm{~kg}$ & 0.05 & 0.12 & 1.01 & 0.29 & & & & & \\
\hline & Sugar & & & 89.7 & & & 89.7 & $1 \mathrm{lb}$ & $1 \mathrm{~kg}$ & 0.06 & 0.37 & 3.00 & 0.87 & & & & & \\
\hline fruits & & & 9.2 & 100.0 & & 12.7 & 100.0 & & & & & & & 0.29 & 0.36 & 0.32 & & 1 \\
\hline & Cabbage & & & 6.7 & & & 7.2 & $1 \mathrm{lb}$ & $1 \mathrm{~kg}$ & 0.04 & 0.08 & 0.90 & 0.26 & & & & & \\
\hline & Onion 1 & & & 5.4 & & & 11.3 & $1 \mathrm{lb}$ & $1 \mathrm{~kg}$ & 0.04 & 0.10 & 1.06 & 0.31 & & & & & \\
\hline & Sweet potato & & & 20.4 & & & 4.1 & $1 \mathrm{lb}$ & $1 \mathrm{~kg}$ & 0.04 & 0.08 & 0.87 & 0.25 & & & & & \\
\hline & Potato & & & 18.5 & & & 33.0 & $1 \mathrm{lb}$ & $1 \mathrm{~kg}$ & 0.02 & 0.08 & 1.47 & 0.43 & & & & & \\
\hline & Spinach & & & 12.1 & & & 8.2 & $1 \mathrm{lb}$ & 1 kan & 0.08 & 0.30 & 0.48 & 0.14 & & & & & \\
\hline & Bananas & & & 18.5 & & & 14.4 & $1 \mathrm{lb}$ & $1 \mathrm{~kg}$ & 0.06 & 0.20 & 1.41 & 0.41 & & & & & \\
\hline & Apples $1, a$ & & & 18.5 & & & 21.6 & $1 \mathrm{lb}$ & $1 \mathrm{~kg}$ & 0.05 & 0.15 & 1.26 & 0.37 & & & & 545 & \\
\hline Processed food & & & 19.1 & 100.0 & & 7.0 & 100.0 & & & & & & & 0.34 & 0.35 & 0.35 & & 1 \\
\hline & vegetable & & & 50.0 & & & 50.0 & $1 \mathrm{lb}$ & $1 \mathrm{~kg}$ & 0.20 & 0.62 & 1.38 & 0.40 & & & & & \\
\hline & salmon $1, a$ & & & 50.0 & & & 50.0 & $1 \mathrm{lb}$ & 1 can (235g) & 0.15 & 0.08 & 1.03 & 0.30 & & & & 120 & \\
\hline Alcohol & & & 4.8 & 100.0 & & 14.5 & 100.0 & & & & & & & 0.48 & 0.48 & 0.48 & & 1 \\
\hline & Beer $a$ & & & 100.0 & & & 100.0 & (946 & 1 bottle ( 720 & 0.27 & 0.33 & 1.63 & 0.48 & & & & 3 & \\
\hline Tea and drinks & & & 1.2 & 100.0 & & 2.6 & 100.0 & & & & & & & 0.36 & 0.36 & 0.36 & & 1 \\
\hline & Tea & & & 100.0 & & & 100.0 & $1 \mathrm{lb}$ & $1 \mathrm{~kg}$ & 0.68 & 1.86 & 1.24 & 0.36 & & & & & \\
\hline Tobacco & Cigarettes $a$ & & 3.9 & 100.0 & & 8.1 & 100.0 & 1 package & 1 package & 0.14 & 0.15 & 1.11 & 0.32 & 0.32 & 0.32 & 0.32 & 704 & 1 \\
\hline Household Utilities & & 4.8 & & & 5.8 & & & & & & & & & 1.06 & 0.89 & 0.97 & & \\
\hline Fuel expenses & & & 52.4 & 100.0 & & 75.6 & 100.0 & & & & & & & 1.21 & 0.88 & 1.03 & & 1 \\
\hline & Coal & & & 12.9 & & & 97.1 & $10 \mathrm{Kg}$ & $1 \mathrm{~kg}$ & 0.00 & 0.03 & 2.96 & 0.86 & & & & & \\
\hline & Firewood $a$ & & & 87.1 & & & 2.9 & $10 \mathrm{Kg}$ & $10 \mathrm{Kg}$ & 0.06 & 0.27 & 4.40 & 1.28 & & & & 6 & \\
\hline Electricity & Electricity & & 47.6 & 100.0 & & 24.4 & 100.0 & $1 \mathrm{kwh}$ & $1 \mathrm{kwh}$ & 0.05 & 0.16 & 3.20 & 0.93 & 0.93 & 0.93 & 0.93 & & 0 \\
\hline Clothing and Bedding & & 10.6 & & & 13.3 & & & & & & & & & 0.25 & 0.49 & 0.35 & & 1 \\
\hline Cloth & & & 33.3 & 100.0 & & 33.3 & 100.0 & & & & & & & 0.65 & 0.72 & 0.69 & & \\
\hline & Raw silk $2, b$ & & & 20.0 & & & 20.0 & $1 \mathrm{lb}$ & $1 \mathrm{~kg}$ & 1.50 & 11.23 & 3.40 & 0.99 & & & & & \\
\hline & Cotton yarn $2, b$ & & & 20.0 & & & 20.0 & $1 \mathrm{lb}$ & $1 \mathrm{~kg}$ & 0.30 & 1.19 & 1.78 & 0.52 & & & & & \\
\hline & Muslin $2, b$ & & & 20.0 & & & 20.0 & 1 yard & 1 yard & 0.15 & 0.49 & 3.22 & 0.94 & & & & & \\
\hline & Woolen yarn $2, b$ & & & 20.0 & & & 20.0 & $1 \mathrm{lb}$ & $500 \mathrm{~g}$ & 1.64 & 2.71 & 1.48 & 0.43 & & & & & \\
\hline & Serge $2, b$ & & & 20.0 & & & 20.0 & 1 yard & $\mathrm{Im}$ & 1.08 & 3.01 & 2.55 & 0.74 & & & & & \\
\hline processing & & & 33.3 & 100.0 & & 33.3 & 100.0 & & & & & & & 0.11 & 0.11 & 0.11 & & \\
\hline & embroiderers & & & 100.0 & & & 100.0 & daily & daily & 0.60 & 1.80 & 0.38 & 0.11 & & & & & \\
\hline Personal Items & & & 33.3 & 100.0 & & 33.3 & 100.0 & & & & & & & 0.65 & 0.65 & 0.65 & & \\
\hline & Men's leather shoes & & & 100.0 & & & 100.0 & 1 pair & 1 pair & 3.73 & 8.25 & 2.21 & 0.65 & & & & & \\
\hline Housing and Furniture & & 10.2 & & & 21.0 & & & & & & & & & 0.59 & 0.75 & 0.66 & & \\
\hline Monthly housing & & & 85.3 & 100.0 & & 69.5 & 100.0 & (assumed & $1.65 \mathrm{sq} . \mathrm{m}$. & 4.77 & 1.06 & 2.69 & 0.79 & 0.79 & 0.79 & 0.79 & 664 & $\mathbf{0}$ \\
\hline Furniture, equipm & ent and supplies & & 14.7 & 100.0 & & 30.5 & 100.0 & & & & & & & 0.24 & 0.68 & 0.40 & & 1 \\
\hline & wage & & & 50.0 & & & 50.0 & hourly & daily & 0.50 & 1.80 & 0.45 & 0.13 & & & & & \\
\hline & Wooden boards & & & 50.0 & & & 50.0 & & & & & & 1.23 & & & & & \\
\hline Miscellaneous Expenses & & 33.2 & & & 26.7 & & & & & & & & & 0.28 & 0.51 & 0.37 & & \\
\hline Transp. \& commu & nication & & 6.2 & 100.0 & & 43.8 & 100.0 & & & & & & & 0.39 & 0.61 & 0.49 & & \\
\hline & and Tokyo) 1 & & & 20.2 & & & 22.9 & 1 ride & 1 ride & 0.05 & 0.10 & 2.00 & 0.58 & & & & & 0 \\
\hline & Gasoline $i$ & & & 20.2 & & & 22.9 & gallon & gallon & 66.50 & 43.50 & & 0.65 & & & & & 1 \\
\hline & rickshaw pullers' & & & 20.2 & & & 22.9 & hourly & daily & 0.58 & 2.70 & 0.54 & 0.16 & & & & & 0 \\
\hline & Automobile & & & 20.2 & & & 22.9 & unit values & unit values & 2587.9 & 601.96 & 4.30 & 1.12 & & & & & 1 \\
\hline & postcard & & & 19.4 & & & 8.3 & 1 piece & 1 piece & 0.01 & 0.02 & 1.50 & 0.44 & & & & & 0 \\
\hline Health and Hygie & & & 23.2 & 100.0 & & 23.3 & 100.0 & & & & & & & 0.21 & 0.58 & 0.35 & & \\
\hline & Doctors' salaries & & & 28.0 & & & 37.1 & annual & annual & 2196.5 & 633.00 & 0.29 & 0.08 & & & & & 0 \\
\hline & pills & & & 28.0 & & & 37.1 & 100 pills & 10 pills & 0.59 & 0.25 & 4.24 & 1.24 & & & & & 1 \\
\hline & Men's haircut $l, a$ & & & 21.6 & & & 14.0 & once & once & 0.39 & 0.40 & 1.04 & 0.30 & & & & 2886 & $\mathbf{0}$ \\
\hline & Toilet soap $1, a$ & & & 22.4 & & & 11.8 & 1 piece & Ipiece & 0.07 & 0.09 & 1.42 & 0.41 & & & & 2838 & 1 \\
\hline Education, books, & and newspapers & & 11.3 & 100.0 & & 8.8 & 100.0 & & & & & & & 0.29 & 0.39 & 0.34 & & 0 \\
\hline & elementary school & & & 23.6 & & & 22.8 & annual & monthly & 2.19 & 0.40 & 2.19 & 0.64 & & & & 1828 & \\
\hline & college and & & & 23.5 & & & 22.7 & annual & monthly & 138.50 & 12.48 & 1.08 & 0.32 & & & & 137 & \\
\hline & Wood pulp & & & 5.3 & & & 5.5 & $100 \mathrm{lbs}$ & $1 \mathrm{~kg}$ & 2.00 & 0.18 & 4.04 & 1.18 & & & & & \\
\hline & Teachers' salary & & & 5.3 & & & 5.4 & annual & monthly & 1974.5 & 65.91 & 0.40 & 0.12 & & & & & \\
\hline & Newspapers $1, a$ & & & 42.3 & & & 43.6 & 1 issue & 1 issue & 0.06 & 0.05 & 0.79 & 0.23 & & & & 74 & \\
\hline Entertainment, rel & gious and welfare & & & & & & & & & & & & & & & & & 0 \\
\hline & Movies $1, a$ & & 59.3 & 100.0 & & 24.1 & 100.0 & per show & per show & 0.29 & 0.30 & 1.03 & 0.30 & 0.30 & 0.30 & 0.30 & & \\
\hline
\end{tabular}

Notes:

1. For Japan, items marked with 1 are the average value for Tokyo in 1934-36, while items marked with 2 are the Tokyo wholesale prices in 1935. All other prices are the 1934-36 averages of consumer prices.

2. For U.S., items marked with "a" are based on micro-data from the Study of Consumer Purchases in the United States (ICPSR 8908), while items marked with "b" are the wholesale prices for the U.S. in 1935.

3. Gasoline prices for US and Japan are from Chugai shogyo simpo 1935.9.26, at http://www.lib.kobe-u.ac.jp/sinbun/eindex.html. Prices are all in Japanese yen.

4. Bus drivers' wages are from the HLS, vol. 1, p. 980. In the case of Japan we used rickshaw wages.

5. For automobiles, unit values with values and quantities in U.S and Japan are from 1939 Census of Manufactures and Factory Statistics respectively.

6. Doctors' salaries for the U.S. is the average of dentists and chiropodists (HLS, vol. II p. 298-300)

7. Teachers' salaries for the U.S. are from Table 12, p. 311 in HLS vol. 11, p. 311. 
8. Electricity prices for the U.S. are from the HLS, vol. 1, p.666-667.

9. Embroiderers' wages for the U.S. are from the HLS, vol. 11, p.94.

10. $1 \mathrm{lb}=453.6$ grams; 1 momme $=375$ grams.

11. Wholesale prices for the U.S. are from the Statistical Abstract 1938. Wholesale prices for Japan are for Tokyo and are from the Historical Statistics of Japan (CD-ROM).

12. U.S. rent data are based on the micro-data of households in two metropolises (New York and Chicago) and six big cities (Providence, RI; Columbus, OH; Atlanta, GA; Omaha-Council Bluffs, NE-IA; Denver, CO; and Portland, OR). The rent includes neither heating nor furnishing.

13. Rent data for Japan are the weighted average of rents in Tokyo and six other big cities (Osaka, Kyoto, Nagoya, Kyoto, Kobe, and Yokohama). As weights, we used the number of households in each city in 1935 (taken from Nihon Teikoku Toukei Nenkan (Statistical Annals of the Japanese Empire), 1938).

14. The average rent per 1.65 sq.m. in Tokyo is from Toukei Shiryou Dai 78 Go (Pre-War Standard Consumption Level Method of Calculation for Tokyo (1), Statistical Materials No. 78) by Keizai Shingicho Chosabu Tokeika (Statistical Survey Department of the Economic Council) (1953). We calculated rent in other cities using information of rent per house (apartment) in Tokyo and the other six cities reported in Clark $(1940,1957)$.

15. For price of wooden boards for making furniture, we use the average of prices for firewood and wood pulp.

16. For medicine pills, prices are for aspirin and cold medicine respectively.

17. For Japan, items marked with 1 are the average value for Tokyo in 1934-36, while items marked with 2 are the Tokyo wholesale prices in 1935. All other prices are the 1934-36 averages of consumer prices.

18. For U.S., items marked with "a" are based on micro-data from the Study of Consumer Purchases in the United States (ICPSR 8908), while items marked with "b" are the wholesale prices for the U.S. in 1935.

19. Bus drivers' wages are from the HLS, vol. 1, p. 980. In the case of Japan we used rickshaw wages.

20. Doctors' salaries for the U.S. is the average of dentists and chiropodists (HLS, vol. II p. 298-300)

21. Teachers' salaries for the U.S. are from Table 12, p. 311 in HLS vol. 11, p. 311.

22. Electricity prices for the U.S. are from the HLS, vol. 1, p.666-667.

23. Embroiderers' wages for the U.S. are from the HLS, vol. 11, p.94.

24. Wholesale prices for the U.S. are from the Statistical Abstract 1938. Wholesale prices for Japan are for Tokyo and are from the Historical Statistics of Japan (CD-ROM).

25. U.S. rent data are based on the micro-data of households in two metropolises (New York and Chicago) and six big cities (Providence, RI; Columbus, OH; Atlanta, GA; Omaha-Council Bluffs, NE-IA; Denver, CO; and Portland, OR). The rent includes neither heating nor furnishing.

26. Rent data for Japan are the weighted average of rents in Tokyo and six other big cities (Osaka, Kyoto, Nagoya, Kyoto, Kobe, and Yokohama). As weights, we used the number of households in each city in 1935 (taken from Nihon Teikoku Toukei Nenkan (Statistical Annals of the Japanese Empire, 1938).

27. The average rent per 1.65 sq.m. in Tokyo is from Toukei Shiryou Dai 78 Go (Pre-War Standard Consumption Level Method of Calculation for Tokyo (1), Statistical Materials No. 78) by Keizai Shingicho Chosabu Tokeika (Statistical Survey Department of the Economic Council) (1953). We calculated rent in other cities using information of rent per house (apartment) in Tokyo and the other six cities reported in Clark (1940, 1957).

28. The price of wooden board is the average of prices of firewood and wood pulp. 


\begin{tabular}{|c|c|c|c|c|c|c|c|c|c|c|c|c|c|c|c|c|}
\hline & \multirow{2}{*}{ Items } & \multicolumn{3}{|c|}{ Chinese weight } & \multicolumn{3}{|c|}{ U.S. weight } & \multirow[b]{2}{*}{ U.S. units } & \multirow[b]{2}{*}{ Chinese units } & \multicolumn{4}{|c|}{ Price } & \multicolumn{3}{|c|}{ Chinese price level } \\
\hline & & $\mathbf{I}$ & II & III & $\mathbf{I}$ & II & III & & & U.S. & China & $\begin{array}{c}\text { China/U.S. } \\
\text { in PPP }\end{array}$ & PPP/ER & $\begin{array}{c}\text { Chinese } \\
\text { weight }\end{array}$ & $\begin{array}{c}\text { U.S. } \\
\text { weight }\end{array}$ & $\begin{array}{c}\begin{array}{c}\text { Fisher } \\
\text { average }\end{array} \\
\end{array}$ \\
\hline Total & Exchange rate & & & & & & & & & Dollar & Yuan & $\begin{array}{l}\mathrm{ER}=3.01 \\
\text { Yuan/US\$ }\end{array}$ & & 0.26 & 0.38 & 0.32 \\
\hline \multirow{12}{*}{ Food Grain } & & 68.7 & & & 33.2 & & & & & & & & & 0.27 & 0.35 & 0.31 \\
\hline & & & 68.5 & & & 12.1 & & & & & & & & 0.29 & 0.40 & 0.34 \\
\hline & Rice & & & 69.9 & & & 3.1 & $1 \mathrm{lb}$ & $1 \mathrm{~kg}$ & 0.08 & 0.14 & 0.77 & 0.26 & 2.73 & 0.01 & \\
\hline & Wheat & & & 30.1 & & & 96.9 & $1 \mathrm{lb}$ & $1 \mathrm{~kg}$ & 0.05 & 0.13 & 1.22 & 0.40 & 0.74 & 0.39 & \\
\hline & fruits & & 8.8 & & & 12.7 & & & & & & & & 0.15 & 0.25 & 0.20 \\
\hline & Potatoes & & & 14.9 & & & 37.1 & $1 \mathrm{lb}$ & $1 \mathrm{~kg}$ & 0.02 & 0.03 & 0.48 & 0.16 & 0.93 & 0.06 & \\
\hline & Cabbages & & & 36.0 & & & 7.2 & $1 \mathrm{lb}$ & $1 \mathrm{~kg}$ & 0.04 & 0.06 & 0.63 & 0.21 & 1.73 & 0.02 & \\
\hline & Spinach a) & & & 36.0 & & & 8.3 & $1 \mathrm{lb}$ & $1 \mathrm{~kg}$ & 0.08 & 0.05 & 0.32 & 0.11 & 3.42 & 0.01 & \\
\hline & Onion & & & 2.3 & & & 11.3 & $1 \mathrm{lb}$ & $1 \mathrm{~kg}$ & 0.04 & 0.03 & 0.32 & 0.11 & 0.22 & 0.01 & \\
\hline & Apples & & & 5.3 & & & 7.2 & $1 \mathrm{lb}$ & $1 \mathrm{~kg}$ & 0.06 & 0.58 & 4.10 & 1.36 & 0.04 & 0.10 & \\
\hline & Oranges $b$ ) & & & 5.3 & & & 7.2 & $1 \mathrm{lb}$ & $1 \mathrm{~kg}$ & 0.25 & 0.38 & 0.69 & 0.23 & 0.23 & 0.02 & \\
\hline & Bananas & & & 0.1 & & & 21.6 & $1 \mathrm{doz}(2 \mathrm{~kg})$ & $1 \mathrm{~kg}$ & 0.33 & 0.40 & 0.55 & 0.18 & 0.00 & 0.04 & \\
\hline \multirow[t]{3}{*}{ Ingredients } & & & 7.4 & & & 3.0 & & & & & & & & 0.67 & 1.23 & 0.91 \\
\hline & Sugar & & & 11.6 & & & 90.0 & $1 \mathrm{lb}$ & $1 \mathrm{~kg}$ & 0.06 & 0.48 & 3.90 & 1.29 & 0.09 & 1.16 & \\
\hline & Salt & & & 88.4 & & & 10.0 & $1 \mathrm{lb}$ & $1 \mathrm{~kg}$ & 0.05 & 0.22 & 1.90 & 0.63 & 1.40 & 0.06 & \\
\hline Meat and Fish & & & 5.9 & & & 40.0 & & & & & & & & 0.26 & 0.32 & 0.29 \\
\hline & Pork & & & 38.1 & & & 5.6 & $1 \mathrm{lb}$ & $100 \mathrm{~g}$ & 0.32 & 0.04 & 0.64 & 0.21 & 1.80 & 0.01 & \\
\hline & Beef & & & 27.0 & & & 8.5 & $1 \mathrm{lb}$ & $100 \mathrm{~g}$ & 0.14 & 0.04 & 1.17 & 0.39 & 0.70 & 0.03 & \\
\hline & Chicken & & & 2.5 & & & 2.3 & $1 \mathrm{lb}$ & $100 \mathrm{~g}$ & 0.29 & 0.07 & 1.09 & 0.36 & 0.07 & 0.01 & \\
\hline & Eggs & & & 5.9 & & & 3.5 & $1 \mathrm{doz}$ & $1 \mathrm{~kg}$ & 0.36 & 0.34 & 0.94 & 0.31 & 0.19 & 0.01 & \\
\hline & Milk & & & 1.4 & & & 12.2 & 1 qt. & 1 bottle & 0.12 & 0.62 & 2.42 & 0.80 & 0.02 & 0.10 & \\
\hline & fish & & & 25.1 & & & 67.9 & $1 \mathrm{lb}$ & $1 \mathrm{~kg}$ & 0.24 & 0.38 & 0.71 & 0.24 & 1.06 & 0.16 & \\
\hline Others & & & 1.0 & & & 7.0 & & & & & & & & 0.09 & 0.09 & 0.09 \\
\hline & Preserved vegetables (Pickles) & & & 100.0 & & & 100.0 & $1 \mathrm{lb}$ & $1 \mathrm{~kg}$ & 0.20 & 0.12 & 0.27 & 0.09 & 11.29 & 0.09 & \\
\hline Drinks and $\mathrm{Tob}$ & acco & & 8.4 & & & 25.2 & & & & & & & & 0.25 & 0.39 & 0.32 \\
\hline & Cigarettes & & & 51.4 & & & 32.12 & 1 package & 1 package & 0.14 & 0.16 & 0.54 & 0.18 & 2.89 & 0.06 & \\
\hline & Beer c) & & & 20.9 & & & 57.50 & 1 quart & 1 bottle & 0.27 & 0.54 & 1.53 & 0.51 & 0.41 & 0.29 & \\
\hline & Tea & & & 27.7 & & & 10.38 & $1 \mathrm{lb}$ & $100 \mathrm{~g}$ & 0.68 & 0.19 & 1.28 & 0.43 & 0.65 & 0.04 & \\
\hline Lighting and Heating & & 8.3 & & & 5.8 & & & & & & & & & 0.70 & 0.92 & 0.80 \\
\hline Electricity & & & 0.3 & 100.0 & & 24.4 & 100.0 & $1 \mathrm{kwh}$ & ${ }^{1} \mathrm{kwh}$ & 0.05 & 0.16 & 3.20 & 1.06 & 1.09 & 1.09 & 1.09 \\
\hline Fuel & & & 99.7 & & & 75.6 & & & & & & & & 0.70 & 0.86 & 0.78 \\
\hline & Coal & & & 23.0 & & & 97.10 & $10 \mathrm{Kg}$ & $10 \mathrm{~kg}$ & 0.04 & 0.11 & 2.62 & 0.87 & 0.26 & 0.84 & \\
\hline & Firewood & & & 77.0 & & & 2.90 & $10 \mathrm{Kg}$ & $10 \mathrm{~kg}$ & 0.06 & 0.12 & 1.99 & 0.66 & 1.17 & 0.02 & \\
\hline Clothing and $\mathrm{Be}$ & dding & 8.5 & & & 13.3 & & & & & & & & & 0.24 & 0.28 & 0.26 \\
\hline Clothing & & & 80.3 & & & 66.7 & & & & & & & & 0.23 & 0.25 & 0.24 \\
\hline & Sweatshirt & & & 50.0 & & & 50.0 & each & each & 1.50 & 1.48 & 0.99 & 0.33 & 1.53 & 0.16 & \\
\hline & Tailors and embroiderers & & & 50.0 & & & 50.0 & daily & daily & 0.60 & 0.32 & 0.53 & 0.18 & 2.82 & 0.09 & \\
\hline Personal items & & & 19.7 & & & 33.3 & & & & & & & & 0.32 & 0.32 & 0.32 \\
\hline & Men's leather shoes $d$ ) & & & 100.0 & & & 100.0 & 1pair & lpair & 2.73 & 2.63 & 0.96 & 0.32 & 3.12 & 0.32 & \\
\hline Housing & & 5.3 & & & 21.0 & & & & & & & & & 0.15 & 0.24 & 0.19 \\
\hline Rent & & & 61.6 & & & 69.5 & & & & & & & & 0.16 & 0.19 & 0.18 \\
\hline & Monthly housing rent $i$ ) & & & 50.0 & & & 50.0 & 1 room & 1 room & 4.77 & 1.72 & 0.36 & 0.12 & 4.17 & 0.06 & \\
\hline & Brick $b$ ) & & & 50.0 & & & 50.0 & 1000pieces & 1000pieces & 11.84 & 9.11 & 0.77 & 0.26 & 1.96 & 0.13 & \\
\hline Furniture & & & 38.4 & & & 30.5 & & & & & & & & 0.14 & 0.37 & 0.22 \\
\hline & Furniture makers' wage & & & 50.0 & & & 50.0 & hourly & daily & 0.50 & 0.91 & 0.23 & 0.08 & 6.62 & 0.04 & \\
\hline & Wooden board $h$ ) & & & 50.0 & & & 50.0 & & & & & & 0.66 & 0.76 & 0.33 & \\
\hline Miscellaneous Expense & & 9.2 & & & 26.7 & & & & & & & & & 0.21 & 0.47 & 0.32 \\
\hline Trans. & & & 4.9 & & & 43.8 & & & & & & & & 0.10 & 0.52 & 0.23 \\
\hline & Bus driver and Rickshaw pullers & 'wage & & 33.3 & & & 50.0 & hourly & daily & 0.58 & 0.54 & 0.12 & 0.04 & 8.61 & 0.02 & \\
\hline & Average railroad fares per passe & nger-km & & 33.3 & & & 30.0 & & & 0.01 & 0.02 & 1.31 & 0.45 & 0.75 & 0.13 & \\
\hline & gasoline & & & 33.3 & & & 20.0 & gallon & gallon & 66.50 & 122.50 & & 1.84 & 0.18 & 0.37 & \\
\hline Educ. & & & 1.5 & & & 5.0 & & & & 0.00 & & & & 0.05 & 0.13 & 0.08 \\
\hline & Teachers' wage & & & 50.0 & & & 50.0 & annual & annual & 1974.50 & 150.00 & 0.08 & 0.03 & 19.81 & 0.01 & \\
\hline & and university $e$ ) & & & 50.0 & & & 50.0 & annual & annual & 138.50 & 100.00 & 0.72 & 0.24 & 2.08 & 0.12 & \\
\hline Hygience & & & 9.9 & & & 6.0 & & & & & & & & 0.31 & 0.43 & 0.37 \\
\hline & Soap & & & 25.0 & & & 22.8 & 1 piece & 1 piece & 0.07 & 0.20 & 3.04 & 1.01 & 0.25 & 0.23 & \\
\hline & Toothbrush & & & 25.0 & & & 22.7 & each & each & 0.28 & 0.21 & 0.75 & 0.25 & 1.00 & 0.06 & \\
\hline & Haircut $g$ ) & & & 50.0 & & & 54.5 & once & once & 0.39 & 0.30 & 0.78 & 0.26 & 1.93 & 0.14 & \\
\hline Medicine & Aspirin $f$ ) & & 5.8 & 100.0 & & 17.3 & 100.0 & 1 bottle & 1 bottle & 0.59 & 1.46 & 2.47 & 0.82 & 0.84 & 0.84 & 0.84 \\
\hline Entertainment & Movie & & 19.2 & 100.0 & & 24.1 & 100.0 & per show & once & 0.29 & 0.20 & 0.69 & 0.23 & 0.24 & 0.24 & 0.24 \\
\hline Other & Newspapers & & 58.7 & 100.0 & & 3.9 & 100.0 & 1 issue & 1 set & 0.06 & 0.04 & 0.63 & 0.21 & 0.22 & 0.22 & 0.22 \\
\hline
\end{tabular}

Source: See Appendix Tables I and II except as noted below

a) The average price of Beijing, Shanghai, Nanjing from China Economic Statistics Annals1934-1935

b) Prices of bricks and orange in the US are from Statistical Abstract of the United States 1938

c) The average price of Wuhan, Chongqing and Shanghai. The units are 1 quart $=946$ milliliters in the US and 1 bottle $=720$ milliters in China

d) Price is for Chongqing.

e) College tuition is the Median value of private colleges reported in "College Tuitions in the 1930s" by Cheng Mingyuan in "Nanfang Zhoumuo", Dec. 4th, 2003.

f) Price is for Morris County, New Jersey 1935 form http://www.gti.net/mocolib1/prices/1935.html; Price for China is for Wuhan. Each bottle is 100 pills.

g) Haircut is calculated as the product of the US-Japan and Japan-China prices.

h) Wooden board uses the price of firewood.

i) One room is 20 square meters in China. 


\section{Appendix A: An Empirical Analysis of the Relationship between Terms of Trade Change and Back- projection Bias}

We empirically test the implication of our theoretical analysis using the data in Heston and Summers (1993). Table 3 of Heston and Summers (1993) reports

$$
\ln \left(\frac{y_{i}{ }^{E}(t, 90)}{y_{E U}{ }^{E}(t, 90)}\right)-\ln \left(\frac{y_{i}{ }^{C}(t)}{y_{E U}{ }^{C}(t)}\right)
$$

for $t=1970,75,80$, and 85 and $i=$ each of 23 OECD countries. The variables with EU denote values for three European countries (the U.K., West Germany and Italy).

The weight consistency effect is only significant for countries experiencing substantial structural change. Since the OECD countries in 1970-90 were already quite developed and relatively homogenous, our statistical test will focus on the terms of trade effect, treating the weight consistency effect as a random error. By taking first differences of equation (A2) over time, we derive the following:

$$
\begin{aligned}
& \left\{\ln \left(\frac{y_{i}^{E}(t+5,90)}{y_{E U}{ }^{E}(t+5,90)}\right)-\ln \left(\frac{y_{i}^{C}(t+5)}{y_{E U}{ }^{C}(t+5)}\right)\right\}-\left\{\ln \left(\frac{y_{i}{ }^{E}(t, 90)}{y_{E U}{ }^{E}(t, 90)}\right)-\ln \left(\frac{y_{i}^{C}(t)}{y_{E U}{ }^{C}(t)}\right)\right\} \\
& =\left\{-\ln \left(\frac{\sum_{n=1}^{N} p_{n}^{G}(t+5) e_{n}^{i}(t+5)}{\sum_{n=1}^{N} p_{n}^{G}(t) e_{n}^{i}(t+5)}\right)+\ln \left(\frac{\sum_{n=1}^{N} p_{n}^{G}(t+5) e_{n}^{E U}(t+5)}{\sum_{n=1}^{N} p_{n}^{G}(t) e_{n}^{E U}(t+5)}\right)\right\}
\end{aligned}
$$

+ error term (composed of weight inconsistency effect and other observation errors)

The first term in the right-hand side of the equation denotes the terms of trade effect.

Let $d_{n}^{i}(t)$ and $x_{n}^{i}(t)$ denote domestic demand and net exports of commodity $n$ in country $i$ in year $t$. We have an equality, $e_{n}^{i}(t)=d_{n}^{i}(t)+x_{n}^{i}(t)$. To simplify the terms of trade effect we make the following additional assumptions.

i) Each country's balance of goods and services trade is close to zero:

$$
\sum_{n} p^{*}{ }_{n}(t) x_{n}^{i}(t)=0 \quad \text { for } \quad \forall t \text { and } \forall i
$$

where $p^{*}(t)$ denotes the international price of commodity $n$ at period $t$.

ii) Each country has a similar demand structure:

$$
a^{i}{ }_{n}(t) / a_{n^{\prime}}^{i}(t)=a^{j}{ }_{n}(t) / a^{j}{ }_{n^{\prime}}(t) \quad \text { for } \quad \forall t, \forall n, \forall n^{\prime}, \forall i \text {, and } \forall j
$$

iii) The GK price vector is close to the domestic price vector of each country and the international price vector.

Then, the first term on the right-hand side of equation (A3) can be approximated by 


$$
-\ln \left(\frac{\sum_{n=1}^{N}\left\{p_{n}^{*}(t+1)-p_{n}^{*}(t)\right\} x_{n}^{i}(t+5)}{\sum_{n=1}^{N} p_{n}^{*}(t) e_{n}^{i}(t+5)}\right)+\ln \left(\frac{\sum_{n=1}^{N}\left\{p_{n}^{*}(t+1)-p_{n}^{*}(t)\right\} x_{n}^{E U}(t+5)}{\sum_{n=1}^{N} p_{n}^{*}(t) e_{n}^{E U}(t+5)}\right)
$$

and, given our assumptions, could be further simplified as follows:

$$
-m^{i}(t+5)\left\{\ln \left(T^{i}(t+1)\right)-\ln \left(T^{i}(t)\right)\right\}+m^{E U}(t+5)\left\{\ln \left(T^{E U}(t+1)\right)-\ln \left(T^{E U}(t)\right)\right\}
$$

where $m^{i}(t+5)$ denotes the simple average of country $i$ 's export-GDP ratio and import-GDP ratio. We call $m$ the trade dependence ratio. $T^{i}(t)$ denotes country $i$ 's terms of trade at time $t$. As the terms of trade effect of the three European countries will affect the PPP gap in the same way, we use time dummies to control for this.

From the above analysis we obtain the following model for our econometric test.

$$
\begin{aligned}
& \left\{\ln \left(\frac{y_{i}{ }^{E}(t+5,90)}{y_{E U}{ }^{E}(t+5,90)}\right)-\ln \left(\frac{y_{i}^{C}(t+5)}{y_{E U}{ }^{C}(t+5)}\right)\right\}-\left\{\ln \left(\frac{y_{i}{ }^{E}(t, 90)}{y_{E U}{ }^{E}(t, 90)}\right)-\ln \left(\frac{y_{i}{ }^{C}(t)}{y_{E U}{ }^{C}(t)}\right)\right\} \\
& =\alpha-\beta m^{i}(t+5)\left\{\ln \left(T^{i}(t+5)\right)-\ln \left(T^{i}(t)\right)\right\}+\sum_{T} \gamma^{T} D U M^{T}(t)+\varepsilon^{i}(t)
\end{aligned}
$$

where $D U M_{T}(t)$ is the time dummy. Since Heston and Summers (1993) report that the current benchmark comparison of 1970 is not fully reliable, we used data for $t=1975,80$, and 85.

The regression using the above equation with the data from Heston and Summers (1993) is tabulated in Appendix A Table, $\beta$, the coefficient of the cross-term of the change in the terms of trade and the trade dependence ratio, is the key variable. Based on our theoretical considerations, we expect $\beta$ to be close to -1 . When a country's terms of trade deteriorate, the extrapolation bias will increase. This effect will be larger for countries with a high trade dependence. Appendix A Table, reporting the results of our regression, shows that the $\beta$ coefficient is close to -1 and statistically significant, thus confirming our theory.

\section{Appendix A Table. The Estimation Result on the Terms-of-Trade Effect}

\begin{tabular}{|cccc|}
\hline & Coefficients & $\begin{array}{c}\text { Standard } \\
\text { error }\end{array}$ & $t$ \\
\hline$\alpha$ & -0.0147 & 0.019 & -0.763 \\
$\beta$ & -0.651 & 0.156 & -4.167 \\
$\Gamma^{80}$ & $3.46 \mathrm{E}-05$ & 0.025 & 0.001 \\
$\Gamma^{85}$ & 0.0943 & 0.025 & 3.751 \\
\hline
\end{tabular}

$R$ square $=0.49$. Sample size is 31 .

Based on these findings, we turn to the terms of trade (TOT) effect for Japan and US between 1935 and 1990 as studied in our paper. The Appendix A Figure presents our terms of trade indices for Japan and US linked from 1935 to 1990. It shows that the US terms of trade deteriorated by 54 percent compared with that of Japan. This would imply, according to our decomposition, an upward bias in the 1930s Japanese per capita income based on the 1990 back-projection, a result consistent with our earlier empirical findings. We quantify the upward bias based on the following formula derived above: $m^{\text {Japan }}(1990)\left\{\ln \left(T^{\mathrm{Japan}}(1990)\right)-\ln \left(T^{\mathrm{Japan}}(1935)\right)\right\}-$ $m^{\mathrm{US}}(1990)\left\{\ln \left(T^{\mathrm{US}}(1990)\right)-\ln \left(T^{\mathrm{US}}(1935)\right)\right\}$. Since trade dependency ratio (the average of exports and imports over GDP) was $10 \%$ for Japan and only $8 \%$ for US in 1990 respectively, the terms of trade improvement for Japan 
between 1935 and 1990 would only account for about 3\% upward bias in the 1990 backward projection method, clearly a small fraction in relation to the $22 \%$ overestimate we found in this study.

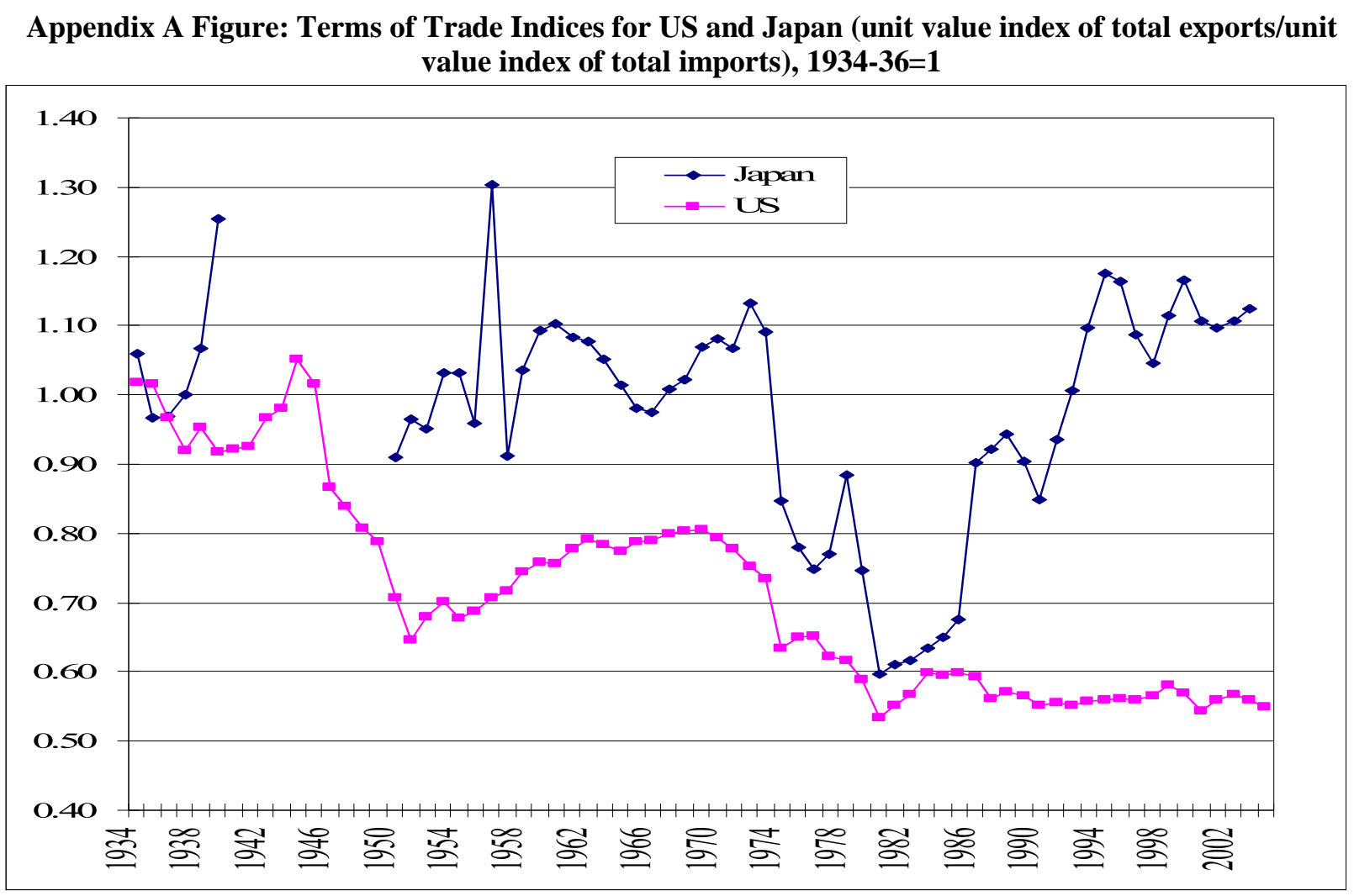

\section{Sources:}

Japan:

1934-54: Estimates of Long-Term Economic Statistics of Japan Since 1868, Vol.14 : Foreign Trade and Balance of Payments, edited by Ippei Yamazawa and Yuzo Yamamoto, Toyo Keizai Shinposha, 1979;

1954-60: Historical Statistics of Japan, Vol.3, 1985, Editorial Supervision: Statistics Bureau, Management and coordination Agency, Japan Statistical Association, Tokyo, Japan;

1960-2000: Nihon Kanzei Kyokai (Japan Tariff Association) "Gaikoku Boeki Gaikyo (General Situation of Japan's International Trade).

US:

1934-55: Historical Statistics of the United States, Bicentennial Edition, Colonial Time to 1970, Part 2, 1975, U.S. Department of Commerce, Bureau of the Census;

1955-84: International Monetary Fund, International Financial Statistics, Yearbook, 1985, International Monetary Fund; 1984-2000: Downloaded from the website of Bureau of Labor Statistics, http://www.bls.gov/data/home.htm.

However, the limited impact of the terms of effect in our empirical test should be carefully interpreted. A major problem is our long-term TOT indices is constructed by linking disparate series where both quantity weights and quality of products (also the number of new products) have changed quite substantially at each linking period. In the case of Japan, there was a hyperinflation and a corresponding huge depreciation of yen after WWII. Our Japan series is based on Yamazawa and Yamamoto's link ratio of TOT between 1934-36 and 1952-54. But due to the change in Japan's trade structure, the number of goods they could match was limited: altogether 163 goods for exports and 135 goods for imports, but only 3 and 12 for export and imports respectively in the case of machinery. The Figure also reveals the highly volatile TOT fluctuation in the short run. All these affect the reliability of our empirical test. 